\title{
PRINCIPLES OF MATRIMONIAL PROPERTY SHARING: ALBERTA'S NEW ACT'
}

\author{
MARGARET A. SHONE*
}

\begin{abstract}
Judicial practice in the division of property upon marriage breakdown led to remedial legislation in the form of Alberta's new Matrimonial Property Act. Interpretation of the new Act, which is limited in scope by its marriage breakdown focus and the provisions for contracting out, will become settled as the case law multiplies. The author discusses some of the issues which will have to be considered by any court in applying the legisla. tion: its similarities with Acts in other Commonwealth countries; the meaning of the pro. perty within the Act; the effect of the presumption of equal sharing; and possible inter. pretations of the guiding factors set out in $s$. 8. The responsibility of ensuring that the Act is interpreted in a remedial spirit is emphasized in conclusion.
\end{abstract}

\section{INTRODUCTION}

In May 1978, after having tested the wind with trial legislation in the fall of 1977,2 the Legislature of Alberta passed an innovative Matrimonial Property Act. ${ }^{3}$ Although a date or dates for proclamation have not yet been fixed, **the Attorney-General has indicated publicly that the Act will probably come into force on January 1, 1979.4 He proffered as the reason for the delay the fact that the Government is "awaiting assurances of federal legislation touching upon taxation matters to ensure that Albertans do not find themselves in a position where they have experienced an unexpected tax problem as a result of a distribution order made pursuant to this act". ${ }^{5}$

The Act is divided into three parts: Part 1 governs the distribution of matrimonial property by a court upon the application of one of the spouses; Part 2 pertains to possession of the matrimonial home; and Part 3 includes provisions of general applicability.

The author's objective in writing this paper has been to shed some light on the principles of sharing contained in Part 1, by concentrating

* Counsel to the Institute of Law Research and Reform Edmonton, Alberta.

** Since the writing of this article, the Matrimonial Property Act was proclaimed November 29, 1978 to come into force January 1, 1979.

1. This article is based on a paper prepared for and presented at a series of seminars entitled "Matrimonial Property Practice - the New Deal" which were offered to legal practitioners throughout the province by the Legal Education Society of Alberta in the fall of 1978. The author is indebted to her fellow L.E.S.A. panelists (Barbara Romaine, Chairperson; Margaret M. Donnelly; Ernest A. Marshall; James D. Miles; Professor Leonard J. Pollock; and John C. Soby), and to those members of the Alberta Bar who attended the seminars and asked questions or made comments, for stimulating many of the further ideas contained in this revision. The writer is also grateful to her colleagues, Professors Christine Davies and Wilbur F. Bowker, each of whom read the article at a stage of draft and made helpful suggestions.

The opinions expressed in this article are held by the author personally, and they do not reflect the position of the Institute of Law Research and Reform except insofar as its Reports have been cited.

2. Bills 102 and 103, Third Session 18th Legislature 26 Eliz. 2, were given second reading and then allowed to die on the order paper.

3. S.A. 1978, c. 22. The Act was introduced on May 4 as Bill 20, Fourth Session 18th Legislature 27 Eliz. 2, given second reading on May 15, and third reading and Royal Assent on May 16, completing its passage through the House in less than two weeks.

4. Alberta Hansard, May 15, 1978 at 1222; October 23, 1978 at 1457.

5. Alberta Hansard, May 15, 1978 at 1222-3. To the writer's knowledge, there have been no alterations in the tax situation to date. 
on analyzing the primary sharing provisions embodied in sections 7 and 8 of that Part. 6 No comprehensive coverage of the Act has been attempted. Nor has it been the writer's intention to debate the merits and demerits of the Alberta Act relative to alternative reforms which might have been adopted. Total neutrality, however, having proven unattainable, the examination is interspersed with observations reflecting personal values.

The paper proceeds in two stages. The text following headings 2 and 3 sets out the backgroud against which Part 1 and, more particularly, sections 7 and 8 should be read and understood. The remainder of the paper is aimed at providing guidance as to the likely interpretation and application of these sections. Here, much reliance has been placed on case law precedent provided for by Commonwealth jurisdiction having similar legislation for, although the concept of matrimonial property sharing is relatively new to legal systems derived from the English common law, the Alberta move follows legislative initiative in New Zealand, the United Kingdom, Australia, and the Canadian jurisdictions of British Columbia, Saskatchewan, the Northwest Territories, and Ontario.?

\section{ECONOMIC CONSEQUENCES OF MARRIAGE}

It is self-evident that social structuring through marriage entails a gradual, complex intertwining of many facets of two lives, one of which is economic. Over the years, legal treatment of the economic incidents of marriage has involved the regulation, in varying combinations, of the capacity to accumulate, own and manage property with the obligation of the spouse in the preferred economic position to maintain or support the other.

In jurisdictions having an English common law tradition, until just over one hundred years ago marriage incapacitated a woman: upon marriage she became, with modest exception, legally incapable of holding property separately from her husband. This defect was rectified in England by a series of Married Women's Property Acts which commenced in 1870. Canadian legislators followed suit. 8

With such legislation, the separate legal status and capacity of a married woman was assured and the system of separation of property came into existence. But a century of experience has demonstrated

6. See Appendix I for a reprint of ss. 7 and 8 of the Alberta Matrimonial Property Act, S.A. 1978, c. 22.

7. E.g. New Zealand: Matrimonial Property Act 1976 (No. 166 of 1976) replacing Matrimonial Property Act 1963 (No. 72 of 1963) as am.; United Kingdom: Matrimonial Causes Act 1973, c. 18, ss. 24, 25, first enacted as the Matrimonial Proceedings and Property Act 1970, c. 45, ss. 4, 5; Australia: Family Law Act 1975 (No. 53 of 1975); British Columbia: Family Relations Act, S.B.C. 1972, c. 20, s. 8; Saskatchewan: Married Women's Property Act, R.S.S. 1965, c. 340, s. 22 as am. S.S. $1974-75$, c. 29 and thereafter; Northwest Territories: Matrimonial Property Ordinance, R.O.N.W.T. 1974, c. M-7; and Ontario: Family Law Reform Act, 1978, S.0. 1978, c. 2.

8. Northwest Territories Act, 49 Vict., c. 25, ss. 36-40; An Ordinance Respecting the Personal Property of Married Women, No. 20 of 1890, c. 47 of the Consolidated Ordinances of the N.W.T., 1898, s. 2; Transfer and Descent of Land Act, S.A. 1906, c. 19, s. 10; The Married Women's Act, S.A. 1922, c. 10; and The Married Women's Act, S.A. 1936, c. 23, now R.S.A. 1970, c. 227. See Jean McBean Worton, "Matrimonial Property", an unpublished research paper prepared for the Institute of Law Research and Reform, June 1972 at $10-18$. 
that this grand stride forward was not enough to fully cure the disabilities wrought upon women by marriage. The simple and continuing fact was that fulfilment of the domestic role of wife and mother - the cultural expectation of the woman in marriage - placed income earning and property acquisition in any substantial amount beyond the reach of most women.

As long as a marriage lasts and is harmonious, society at large and the couple themselves can tolerate the economic inequality brought about by marriage. Indeed, it may be expected that, either through tacit understanding or by conscious decision, any given couple will order their lives so as to effect a division of labour and responsibility in every sphere which is mutually agreeable and beneficial to them.

When the marriage breaks down, however, or is terminated, the consequences of the economic enmeshment of the affairs of the spouses during marriage take on greater significance. The existing law resolves the problem of economic disparity in their positions by imposing a duty on the economically stronger spouse to maintain the other. But there are limitations to this solution. The amount of such financial support is based on the needs of the claimant spouse, traditionally the wife, measured against the means and resources of the other. It does not constitute an earned entitlement. It bears little or no relationship to the number of years, or extent, of past dedication to the marriage, and it may fluctuate with the future circumstances of each of the spouses. In the past, the recipient could become disentitled by leading a less than chaste sex life, even following divorce, and the right to receive support may still be lost by reason of behaviour following the breakdown or termination of the marriage, as in the case of remarriage. Moreover, the collection mechanisms provided by the legal system are cumbersome, expensive, and often ineffective. This is especially true where the payment of support is periodic.

On the property side, only limited recognition is accorded to the contribution which one spouse may make to property owned or acquired by the other spouse, a fact which renders it extremely difficult to make out the right to a declaration of a beneficial interest in such property. Absent an express common intention to share, the claimant spouse is required to adduce evidence from which the court may imply such an intention through a showing of direct contribution in money or in its equivalent - for example, in the form of labour - to the asset in question. The showing required of a spouse is even greater than that of a stranger, a point which was forcefully driven home to Canadians by the Supreme Court of Canada decision in Murdoch v. Murdoch .9 In that case, which originated in Alberta, the couple lived together for 25 years (from 1943 to 1968). During their early years of marriage, they worked as a hired couple on several ranches. Their earnings were paid to the husband, and his savings enabled them to make the first of a series of purchases of ranch properties and other assets - always in his own name. The facts revealed no express common intention of the parties to share the properties which formed the subject-matter of dispute, being those he owned at separation, 
and no clearly direct financial contribution to them on the part of the wife. A four-man majority of the Supreme Court of Canada10 rejected the wife's attempt to prove her entitlement to a declaration of beneficial interest in the properties on the basis of indirect contribution. They agreed with the trial judge that "what the appellant had done, while living with the respondent, was the work done by any ranch wife"." According to the testimony of the wife, in which the husband concurred, that work included:12

Haying, raking, swathing, moving, driving trucks and tractors and teams, quietening horses, taking cattle back and forth to the reserve, dehorning, vaccinating, branding, anything that was to be done.

What is more, from 1947 on the wife ran the ranch herself during the day for some five months of the year while her husband was away from home on other work.13 Women across Canada were inflamed by the result and the case acted as a major catalyst for legislative reform.

Curiously enough, the same judiciary which has taken a rigidly selflimiting approach to its power to declare a beneficial ownership in property belonging to a spouse has striven valiantly on the maintenance front to compensate for its lack of power to distribute property on divorce. Large lump sum awards, often approximating half the equity in the matrimonial home and hardly attributable to on-going or present needs, are frequently ordered. These awards emanate very much the flavour of compensation for past efforts or, possibly, for the economic detriment suffered by a spouse whose devotion to the marriage has supplanted career and the opportunity to accumulate property.

\section{DISSATISFACTION WITH THE PRESENT LAW}

In recent years, unfairness stemming from the operation of the law of separation of property has been the subject of growing criticism. The relative ease of divorce, particularly since the enactment in 1968 of the federal Divorce Act, ${ }^{4}$ has probably influenced the political tide. As well, where divorce does take place it is frequently followed by a new alliance, and existing support laws are out of step with this tune. With the divorce rate in Canada currently running upwards of 20 per cent, and in the vicinity of 30 per cent in Alberta, 15 the justification for legislation which plans for the eventuality of future parting rather than life-long togetherness is strengthened. The advent of effective means of birth control and the opening up of the business world and professions to women comprise similarly cogent forces of unrest. Economic dependency is no longer the unavoidable condition of married women. As more options become realistically available to women and, indeed, to both sexes, a couple's decision that one of them - usually the wife, even today - shall stay at home entails a more

10. Martland J. (Judson, Ritchie and Spence concurring). Laskin J., as he then was, registered the lone dissent.

11. [1975] 1 S.C.R. 423 at 436.

12. $I d$. at 443 .

13. Id. at $443-4$.

14. R.S.C. 1970 , c. D-8.

15. Statistics Canada, No. 84205, Vital Statistics Vol. 2, Marriages and Divorces - 1976 , Ottawa, August 1976. 
recognizable economic sacrifice on the part of that spouse, and helps to explain increasing demands for a share in the property accumulated by the spouse who remains free to venture outside the home and enhance his wealth.

Widespread public support for the notion of sharing of matrimonial property is reflected in the extensive responses of law reform bodies 16 and governments ${ }^{17}$ across Canada and elsewhere in the common law world. But, whereas the notion of sharing has a uniform following, the consensus stops short of the means of achieving that sharing. The reforming current embraces three schemes alternative to the present system of separation of property. These may be succinctly described as community of property, deferred sharing and judicial discretion.18

The idea of community of property prevails in jurisdictions enjoying a civil law tradition of jurisprudence. It constituted the legal regime in

16. In Canada, reports have been issued by law reform agencies in seven provinces including Quebec. These are: the Quebec Civil Code Revision Office, Report on Matrimonial Regimes, Montreal, 1968; the Newfoundland Family Law Study Project VIII, Property Rights in the Family, Final Report, St. Johns, 1970; Ontario Law Reform Commission Family Law Project, Report on Family Law, Part IV, Family Property Law, Toronto, Ministry of the Attorney General, 1974; British Columbia Royal Commission on Family and Children's Law, Report on Matrimonial Property, 6th report, Vancouver, 1975; Alberta Institute of Law Research and Reform, Report No. 18, Matrimonial Property, Edmonton, 1975; Manitoba Law Reform Commission, Reports on Family Law, Part II, Property Disposition, Winnipeg, 1976; Saskatchewan Law Reform Commission, Proposals for a Saskatchewan Homes Act, Report to the Attorney General, Saskatoon, 1976. In addition, the Nova Scotia Law Reform Advisory Commission has published a study entitled The Development of Matrimonial Property Law in England and Nova Scotia, an Historic Perspective, Halifax, 1975. This paper, prepared by Lilias M. Toward, Q.C., was intended to serve as the factual basis for further study by the Commission.

The Law Reform Commission of Canada has also made recommendations in its Report on Family Law, Ottawa: Information Canada, 1976.

Elsewhere, the English Law Commission has issued a series of three reports on family property: Family Law, First Report on Family Property: a New Approach, Law Com. No. 86, London H.M.S.O., 1978. In the United States, the National Conference perty: Family Provision on Death, Law Com. No. 61, London H.M.S.0., 1974; and Family Law, Third Report on Family Property and the Matrimonial Home, Law Com. No. 86, London H.M.S.O., 1978. In the United States, the National Conference of Commissioners on Uniform State Laws has dealt with the topic in s. 307 of the Uniform Marriage and Divorce Act, Uniform Laws Annotated, St. Paul, Minnesota: West Publishing Co. Vol. 9, Matrimonial, Family and Health Laws, Supplementary Pamphlet 1974 to 1977.

17. In addition to the Matrimonial Property Act now under discussion, S.A. 1978, c. 22. and those statutes which have spawned the jurisprudence relied upon in this paper (see supra n. 7) legislation has been passed in the Canadian provinces of: Quebec, The Legal Regime of Partnership of Acquests. Civil Code, Book Third, Title Fourth, Chapter First A. Articles 1266c to 1267d adopted in 1970; Prince Edward Island, Family Law Reform Act, S.P.E.I. 1978, c. 6; Manitoba, The Marital Property Act, S.M. 1978, c. 24; and British Columbia, Family Relations Act, S.B.C. 1978, c. 20. The Prince Edward Island Legislation received Royal Assent on July 12, 1978 and will take effect after December 31, 1978. The Manitoba Act received Royal Assent on July 20, 1978 and was proclaimed in force on October 15, 1978. At the time of writing no date had yet been set for proclamation of the British Columbia statute which received Royal Assent on June 29, 1978 and which will eventually replace the present Family Relations Act, S.B.C. 1972, c. 20 including s. 8 . The Nova Scotia government presented a bill entitled An Act Respecting the Property of Married Persons (Bill No. 15, 5th Session 51st General Assembly 27 Eliz.2,1978) to the Legislature. The bill was referred to Committee after first reading, but the Committee did not report before the summer election and the resultant change of government.

18. Institute of Law Research and Reform, Working Paper on Matrimonial Property, Edmonton, April 1974. 
the province of Quebec prior to 1970. In full community, all property owned by either husband or wife at marriage and property acquired afterwards is the common property of both although, traditionally, the husband has sole control or management of it. Often full community is modified, for example, to exclude property owned before marriage or a gift from a third party or to provide for its administration jointly by husband and wife. The system possesses the advantage of recognizing marriage as a cooperative venture. Furthermore, the property rights of husband and wife are present and certain. In 1975, the British Columbia Royal Commission on Family and Children's Law ${ }^{19}$ recommended the enactment of a scheme of community of property for that province, and at one stage in the legislative evolution of Manitoba's Marital Property Act 20 it was endorsed for family assets. Community of property forms the basis of the present law in some American states, including California, Washington and Texas. However, it has fallen into disfavour in those jurisdictions - such as Sweden, Denmark, Norway and the Federal Republic of Germany where it grew up.

Deferred sharing represents a middle road between separation of property and community of property. Under this scheme, husband and wife each own their own property separately while the marriage continues. Upon marriage breakdown or dissolution, separate calculations are made of the total value of the property owned by each spouse at that time, less debts and the value of property owned before marriage and of gifts and inheritances from third parties during marriage. Equalization is achieved by a payment from the spouse with the higher balance to the spouse with the lower balance in the amount of one-half the difference between the two net figures. To satisfy the debt thereby created, a court may direct the payment of a sum of money or the transfer of property. However, the form of the order does not alter the fact that the sharing is of net gains during marriage and not of assets individually. Deferred sharing is the common law world counterpart of the legal regime of "partnership of acquests" which was introduced into Quebec in 1970.21 It was the choice of the Royal Commission on the Status of Women22 and one or another formulation has been recommended for adoption by the Ontario Law Reform Commission,23 and the majority of the members of the Board of Directors of the Alberta Institute of Law Research and Reform. ${ }^{24}$

19. Report on Matrimonial property (6th Report), Vancouver, 1975.

20. S.M. 1978, c. 24.

21. Civil Code, Book Third, Title Fourth, Chapter First A, Articles $1266 \mathrm{c}$ to $1267 \mathrm{~d}$.

22. Sept. 28, 1970, Information Canada, Ottawa. Chapter 4, paragraph 89 reads: “. . [W]e recommend that those provinces and territories, which have not already done so, amend their law in order to recognize the concept of equal partnership in marriage so that the contribution of each spouse to the marriage partnership may be acknowledged and that, upon the dissolution of the marriage, each will have a right to an equal share in the assets accumulated during marriage otherwise than by gift or inheritance received by either spouse from outside sources."

23. Family Law Project, Report on Family Law, Part IV, Family Property Law, Report to Ministry of the Attorney General, Toronto, 1974.

24. Report No. 18, Matrimonial Property, Edmonton, August 1975. The Matrimonial Property Act which was subsequently enacted did not adopt this position. See infra heading IV, Response of the Alberta Legislature. 
The third commonly discussed alternative for reform is judicial discretion. Under this scheme, the court is empowered to decide what is fair and to order a decision which is just in the circumstances of the individual case, usually having regard to named criteria of which the most salient, by far, is the efforts expended by each spouse in contribution to the marriage and the acquisition of property. The outstanding advantage of judicial discretion is its flexibility to meet the merits of the individual case. On the other. hand, this system does not supply the same degree of certainty as do the first two alternatives. It is the reform which was favoured by the minority of members of the Board of Directors of the Alberta Institute of Law Research and Reform ${ }^{25}$ and differing versions have been legislated in England, Australia, British Columbia, Saskatchewan and the Northwest Territories. ${ }^{26}$

Most reform measures involve some accommodation of the separate goals of certainty and flexibility represented by full community of property on the one hand and judicial discretion on the other. By way of example, recommendations have been made to combine the certainty of a provision for co-ownership of the matrimonial home frequently the couple's sole major asset - with the essentially discretionary schemes already in force in England27 and Saskatchewan.28 Furthermore, the various renditions of deferred sharing usually include a discretion to adjust the balancing payment on extreme facts.

In addition to the flurry of activity in the legislative arena, there are signs of reaction to the same public outcry and pressures by the judiciary. In particular, the judgment of the Supreme Court of Canada in Rathwell v. Rathwell ${ }^{29}$ has attracted considerable public acclaim and juristic comment. ${ }^{30}$ The case involved properties, held in the name of the husband, which had been acquired by a Saskatchewan farm couple during the 23 years (from 1944 to 1967) transpiring between their marriage and separation. The facts were close to those in Murdoch, in that while the marriage subsisted both spouses played an integral part in the farming operation, but they were also distinguishable in two important respects: there was evidence, out of the mouth of the husband, of the couple's intention to work as a team; and the court was able to trace the acquisitions back to original purchase monies withdrawn from a joint bank account into which the

25. Id.

26. United Kingdom: Matrimonial Causes Act 1973, c. 18, ss. 24, 25; Australia: Family Law Act 1975 (No. 53 of 1975); British Columbia: Family Relations Act, S.B.C. 1972, c. 20 , s. 8; Saskatchewan: Married Women's Property Act, R.S.S. 1965 , c. 340, s. 22 as am S.S. 1974-1975, c. 29 and thereafter; and Northwest Territories: Matrimonial Property Ordinance, R.O.N.W.T. 1974, c. M-7.

27. The English Law Commission, Third Report on Family Property: The Matrimonial Home (Co-ownership and Occupation Rights) and Household Goods, Law Com. No. 86, London H.M.S.O., 1978.

28. Saskatchewan Law Reform Commission, Proposals for a Saskatchewan Homes Act, Report to the Attorney General, Saskatchewan, 1976.

29. [1978] 2 W.W.R. 101 (S.C.C.).

30. N. Ferra, "A Comment on Rathwell v. Rathwell," (1978) 1 R.F.L. (2d) 34; B.C. Howell, "Rathwell v. Rathwell - The Constructive Trust Revisited" (1978) 1 E.T.R. 309; L.J. Pollock. "Matrimonial Property and Trusts: The Situation from Murdoch to Rathwell" (1978) XVI Alta. L. Rev. 357; R.L. Walker, "Constructive Trusts in Matrimonial Property Law," (1978) 1 Can. J.F.L. 303. 
husband and wife each had deposited about $\$ 700$ early in their marriage. Thus, there was evidence both of express common intention and of direct financial contribution on the wife's part - circumstances which bore out the presumption of resulting trust such that, to the extent of the intention so found, the husband held a beneficial interest in the lands for her. The nine members of the Court, who were in agreement to this point, split on the issue of the extent of the wife's interest, a five-man majority ${ }^{31}$ granting her an equal interest in all the properties accumulated during marriage and the four-man minority ${ }^{32}$ reducing this to an equal interest in just four of the more than eight quarter sections of land in dispute. Two of these four had been, for a time, the homestead of the couple.

The cases of Murdoch ${ }^{33}$ and Rathwell 34 accent the vastly disparate results possible on similar facts under the existing law, and bring into question the suitability of its principles to resolve issues of property ownership in a domestic context. Both cases involve long-term marriages ( 23 years in one case, 25 in the other). Neither couple can be said to have initiated married life anticipating marriage breakdown. Both worked long and hard together over the years to improve their economic lot and, during the course of their respective marriages, succeeded in acquiring agricultural lands of increasingly substantial worth to which the husband took legal title. Upon marriage breakdown, one wife is held entitled to an equal share in all the properties amassed during marriage; the other receives no share at all. The difference is due largely to chance arrangements made by the couple, and little to deliberate plan. As Mr. Justice Dickson stated in the Rathwell decision:35

The manner in which title in registered may or may not be of significance in determining beneficial ownership. The state of legal title may merely reflect conformity with regulatory requirements, such as those under the Veterans' Land Act, which stipulate that the veteran must make the application; it may, on the other hand, be a matter of utmost indifference to spouses as to which name appears on the title, so long as happy marriage subsists; the manner in which title is recorded may simply reflect the conveyancing in vogue at the time as, for example, the practice in Western Canada of placing title to farmland in the name of the husband. The state of title may be entirely fortuitous; it should not be taken as decisive against the non-titled party.

The significance of Rathwell, ${ }^{36}$ however, does not lie in its result on the facts. ${ }^{37}$ Rather, it is attributable to the endorsement, albeit in obiter dicta, by three of the majority members of the Court ${ }^{38}$ of the

31. Dickson J. (with Laskin C.J.C. and Spence J. concurring) and Ritchie J. (with Pigeon J. concurring).

32. Martland J. (with Judson, Beetz and De Grandpre JJ. concurring).

33. [1975] 1 S.C.R. 423.

34. [1978] 2 W.W.R. 101.

35. Id. at 114 .

36. Id.

37. Other cases have gone as far. Trueman v. Trueman [1971] 2 W.W.R. 688 (Alta. A.D.) is a leading Alberta example.

38. Dickson J. (Laskin C.J.C. and Spence J. concurring). The two remaining members of the majority, Ritchie J. (Pigeon J. concurring), did not consider it necessary to make "any determination as to the application of the doctrine of constructive trusts or unjust enrichment," Rathwell v. Rathwell [1978] 2 W.W.R. 101 at 122. The minority specifically rejected its application to matrimonial property disputes. 
constructive trust as a remedial device through which to achieve an equitable result by preventing the unjust enrichment of the husband at the expense of his wife, and to their downgrading of the importance in a matrimonial context of the formalities of the law of property which adhere in other situations. The position of this trio is lucidly expressed by Mr. Justice Dickson who rendered their judgment: ${ }^{39}$

The constructive trust . . . comprehends the imposition of trust machinery by the court in order to achieve a result consonant with good conscience. As a matter of principle, the court will not allow any man unjustly to appropriate to himself the value earned by the labours of another. That principle is not defeated by the existence of a matrimonial relationship between the parties; but, for the principle to suceed, the facts must display an enrichment, a corresponding deprivation and the absence of any juristic reason - such as a contract or disposition of law - for the enrichment ...

The emergence of the constructive trust in matrimonial property disputes reflects a diminishing preoccupation with the formalities of real property law and individual property rights and the substitution of an attitude more in keeping with the realities of contemporary family life.

What is more, the same three members expressly dissociated themselves from certain conclusions suggested by the Murdochto judgment: 41

However, having recognized that the Murdoch decision is distinguishable in various ways, I wish also to say this: to the extent that Murdoch stands for the proposition that a wife's labour cannot constitute a contribution in money's worth and to the extent that Murdoch stands in the way of recognition of constructive trust as a powerful remedial instrument for redress of injustice, I would not, with utmost respect, follow Murdoch.

Judgments such as Rathwell 42 and those since recognizing the constructive trust as a remedy appropriate in the matrimonial context $\mathrm{t}^{43}$ are encouraging. Nevertheless, they have come too late to quell the reforming momentum built up following Murdoch by restoring public confidence in the capability of judge-made law to mend the inadequacies of separation of property when husband and wife part.

\section{RESPONSE OF THE ALBERTA LEGISLATURE}

Cognizant of the reforming fervour, the Legislature of Alberta has met the dissatisfaction with the present law by enacting a Matrimonial Property Act 44 which, in Part 1, gives the court a wide latitude to apportion the property of the spouses in a manner which is fair in all the circumstances of their case. That is to say, the essence of the legislation, which seems to have originated in the main from the minority recommendations of the Report of Alberta's Institute of Law Research and Reform, ${ }^{45}$ is judicial discretion. But it is a discretion tempered with certainty by the inclusion of a number of characteristics commonly thought of in conjunction with a scheme of deferred sharing notably, by the division, in section 7 , of property into categories to which different sharing considerations apply and by the exemption

39. Rathwell v. Rathwell [1978] 2 W.W.R. 101 at 113.14.

40. $\{1975] 1$ S.C.R. 423.

41. Rathwell v. Rathwell [1978] 2 W.W.R. 101 at 122.

42. Id.

43. See e.g., Babrociak v. Babrociak [1975] 1 R.F.L. (2d) 95 (Ont. C.A.) and Re Sawyers and Sawyers [1978] 85 D.L.R. (3d) 139 (Ont.H.Ct.).

44. S.A. 1978 , c. 22.

45. Supra n. 24. 
of certain valuated amounts from sharing. To this extent, the Act entails a compromise of divergent positions being propounded by different constituents of the electorate. In the further interests of certainty, the court is obliged to have regard to thirteen criteria named in section 8, the most outstanding being contributions to the marriage and to property, before making a matrimonial property order.

As indicated in the Introduction, the remainder of this paper will be devoted to an examination of these sections in detail with a view to suggesting their likely interpretation in light of the experience under recently enacted matrimonial property legislation in New Zealand, the United Kingdom, Australia, British Columbia, Saskatchewan, the Northwest Territories and Ontario. ${ }^{46}$ But the assumption that experience elsewhere will assist in the prediction of outcomes under the Alberta Act is one to be approached with caution for, however similar the subject-matter of such other legislation, the differences in policy couched in its structure and language may render the comparison nugatory. For example, the English and Australian legislation combines the power to adjust the ownership of property together with the power to order the payment of support - all to the end of fair "financial provision;" the Alberta statute, on the other hand, is limited to the distribution of property between spouses. In Ontario and New Zealand, under the 1976 Act, the sharing principles differ for "family" and other assets, equal sharing being the rule for "family" assets; the Alberta legislation draws no such distinction.

The most useful analogies may be drawn from the contributionbased judicial discretion provided for in the 1963 New Zealand Act47 and subsequent amendments, and from the Saskatchewan ${ }^{48}$ and Northwest Territories ${ }^{49}$ adaptations of it, for they embody the essential feature of the Alberta provisions although in Alberta the discretion is somewhat more fettered by the separation of property into three different categories for sharing. The judicial refinement of British Columbia's ${ }^{50}$ otherwise unguided discretion is also helpful.

\section{LIMITATIONS ON SCOPE OF ACT}

Before launching into an analysis of the contents of sections 7 and 8 of Alberta's Matrimonial Property Act, two important limitations on its scope of application deserve mention. First, the sharing provisions of the Act are available only to a living spouse whose marriage has broken down, as evidenced by the fact that the spouses are living separate and apart. Secondly, spouses are under no compulsion to seek a distribution under the Act; instead they may rely on their rights under the law of separation of property or they may agree to share in some other way.

46. Supra n. 7.

47. Matrimonial Property Act 1963 (No. 72 of 1963).

48. Married Women's Property Act, R.S.S. 1965 , c. 340, s. 22 as am. S.S. $1974-75$, c. 29 and thereafter.

49. Matrimonial Property Ordinance, R.O.N.W.T. 1974, c. M-7.

50. Family Relations Act, S.B.C. 1972, c. 20, s. 8. 


\section{A. Marriage Breakdown Focus}

Despite its title, the Matrimonial Property Act does not create a generally applicable property regime for husband and wife. Part 1 fulfils the much narrower purpose of providing for the distribution of marital property upon marriage breakdown. Section 5 stipulates that a matrimonial property order may be made only after decree nisi of divorce, declaration of nullity, judgment of judicial separation, one year's separation (or less if there is no possibility of reconciliation), or on separation coupled with the fact or intention of one spouse to transfer or make a substantial gift of property to a third party to defeat a claim by the other spouse under the Act, or with the dissipation of property to the other spouse's detriment.51 On a superficial reading, subsection (1) of section 11 appears to extend the ambit of the court's jurisdiction to include a marriage brought to an end by the death of one spouse. However, subsection (2) imports the conditions laid down in section 5 for the granting of an order while the two spouses are alive.

One consequence of the marriage breakdown focus is that a spouse in a weaker asset position who forbears rather than separates may be penalized for sticking with the marriage. Apart from the incursions made by the Family Relief Act,52 the spouse who has been aided in his business and property efforts by the functional division of labour within the marriage still has relatively unbridled testamentary freedom over his acquisitions. For a conventional marriage, this could mean "that the wife whose economic self-abnegation has enabled [her husband] to make [a proprietary accumulation] might be left penniless in widowhood". .53

Whatever the logic of excluding marriages dissolved by death from the principles of sharing, the narrow compass of the Act means that the legal practitioner must keep abreast of developments under two totally different sets of rules for the distribution of matrimonial property - those found in the Act and those provided by the existing law. Where ownership is required to be decided prior to marriage breakdown, or after the termination of a viable marriage by death of one

51. In support of the constitutionality of provincial legislation which provides for the division of matrimonial property on divorce, nullity or judicial separation, see Weist v. Weist (1977), 30 R.F.L. 395 at 396 , rejecting the argument "that settlement of property upon a spouse following dissolution of marriage is either a necessary incident of marriage or, alternatively, of divorce, as the jurisdiction of the courts to make such an order is dependent upon the married status and for effect, upon dissolution."

52. R.S.A. 1970, c. 134. This Act has as its purpose the protection of dependants from the irresponsible use, by providers, of the freedom of testation. It is founded on principles of maintenance provision rather than of property division, and there is concern even today over the ease with which the protection accorded dependants can be circumvented by outright gift, or by setting up a trust. See Report No. 29, Family Relief, The Institute of Law Research and Reform, Edmonton, June 1978, at 1.

53. Haldane v. Haldane [1976] 2 N.Z.L.R. 715 (P.C.) at 721 (Lord Simon of Glaisdale). At one of the L.E.S.A. seminars, a practitioner questioned whether a bequest under a will could amount to an intended gift or transfer to a third party for the jurisdiction conferring purposes of section $5(1)(\mathrm{i})$ or (ii). Of course, even if argument on this head were to succeed, the other limb of the jurisdictional requirement would also have to be met: the spouses would have to have been living separate and apart just prior to the death of the propertied spouse. 
spouse, or for purposes of the categorization of property as shareable or exempt under the Matrimonial Property Act,54 the judicial evolution of the principles of resulting trust will continue to carry great significance. The law as enunciated in cases such as Murdoch ${ }^{55}$ and Rathwell56 still matters.

\section{B. Provision for Contracting Out}

As stated above, separated or divorcing spouses are not obliged to resort to the distribution provisions of the Matrimonial Property Act. If they are satisfied with their proprietary interests under the principles of separation of property as they are presently developing in our courts, the couple may leave their rights at that. This spouses preferred to do in Australia prior to 1975 notwithstanding the more general power in the divorce court to adjust property interests. ${ }^{57}$

Alternatively, spouses may escape the reaches of a matrimonial property order by entering into a written contract dealing with "the status, ownership and division of property, including future property, owned by either or both of them." That is to say, the sharing principles spelled out in Part 1 are available only in the absence of agreement between the spouses entered into by virtue of the permission extended to them by the selfsame Act. The sanctioned contract may be entered into either in contemplation of marriage or thereafter and, in a pronounced departure from the present law, the couple are allowed to plan for the contingency of separation or divorce. Formalities are made requisite by section $38.5^{58}$ It seems unlikely that the Legislature intended to preclude the operation of Part 1 of the Act where the spouses have entered into an enforceable agreement which extends to some but not the whole of their property. However, the opening words of section 37(1) declare that "Part 1 does not apply to spouses who have entered into a subsisting agreement in writing with each other that is enforceable under section 38." Because the reference is to the "spouses" instead of to the "property" which is the subject-matter of the contract, a strict reading of the section would put spouses who have contracted in respect of any property out of the Act altogether.

By specifically countenancing contracting out, the Act preserves substantially unblemished the legal autonomy of spouses, as adult persons of full capacity, to conduct their own affairs as they see fit.

54. See heading IX.B below.

55. [1975] 1 S.C.R. 423; [1974] 1 W.W.R. 361.

56. $[1978] 2$ W.W.R. 101 (S.C.C.).

57. J. Neville Turner, "Confusion in English Family Property Law - Enlightenment from Australia?" (July 1975) 38 M.L.R. 397 at 405. The former Australia situation is described more fully below under heading IX.B.

58. In order to avoid the effect of Part 1 of the Matrimonial Property Act, the contract recognized by section 37 must be in writing and each spouse must acknowledge separately from the other that he is aware of the nature and effect of the agreement, of his possible future claims to property under the Act and his intention to give them up insofar as the agreement renders it necessary, and that the execution is free and voluntary and without compulsion. The acknowledgment must be made before a lawyer who does not act for the other spouse and who has not witnessed the other spouse's acknowledgement. 


\section{APPROACH TO INTERPRETATION}

Albertans should not expect a smooth reception of the Matrimonial Property Act into practice. Confusion has attended the legislative introduction, in other common law jurisdictions, of principles for the sharing of marital property. The "divergencies of view and of practice" which had grown up in England following the enactment of legislation in $1970^{59}$ were not dispelled until three years later when guidelines were set out by the Court of Appeal, in Wachtel v. Wachtel,60 in response to the complaint of counsel that they were "unable to advise their clients with a reasonable degree of certainty as to the likely outcome of any contested proceedings". ${ }^{61}$ In his judgment, Lord Denning recognized the desirability of removing that uncertainty and of assisting parties to come to agreement. Appellate courts also have been called upon to resolve dilemmas of interpretation in New Zealand,62 and in British Columbia.63

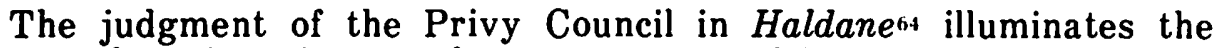
approach to be taken to the construction of innovative matrimonial property legislation. Viewing the 1963 New Zealand statute65 as "extraordinarily difficult to construe, as can be seen by the great diversity of judicial opinion that it has evoked,"66 their Lordships turned to the New Zealand counterpart of sections 11 and 6(1) of Alberta's Interpretation Act 6 7 - which seemed to them "to give statutory force to ... 'the rule in Heydon's Case' "'s - and adopted a remedial approach to construction. That is to say, they first endeavoured "to ascertain what was conceived to be wrong with the New Zealand matrimonial property law before 1963"..14

The English Court of Appeal took a similar approach in Wachtel,70 but without resort to statute. In the judgment of the Court, Lord Denning methodically identified the mischief which Parliament intended to cure as a means to placing a correct interpretation upon the legislation passed to remedy it.71

In light of the above authority, it is submitted that the proper approach to interpretation of the new Alberta Act involves addressing the question: what is wrong with the present law such that the Legislature has been prompted to intervene? The Attorney-General answered the question in the House when he described the failure to credit the contribution of the homemaker spouse as "singularly the most

59. Matrimonial Proceedings and Property Act 1970 (U.K.), c. 45, ss. 4, 5.

60. [1973] 1 All E.R. 829.

61. Id. at 833 .

62. E. v. E. [1971] N.Z.L.R. 859 (C.A.); Haldane v. Haldane [1976] N.Z.L.R. 715 (P.C.).

63. Deleeuw v. Deleeuw (1977) 82 D.L.R. (3d) 522 (B.C.C.A.).

64. [1976] N.Z.L.R. 715.

65. Matrimonial Property Act 1963 No. 72 of 1963.

66. Haldane v. Haldane [1976] 2 N.Z.L.R. 715 at 719-20.

67. R.S.A. 1970 , c. 189.

68. (1584) 3 Co. Rep. 7A, 76 E.R. 637.

69. Haldane v. Haldane [1976] 2 N.Z.L.R. 715 at 720.

70. [1973] 1 All E.R. 829 (C.A.).

71. Id. at $835-9$. 
significant deficiency in the law today".72 Although this source would not be available to the court as an aid to the construction of the statute, a situation perhaps to be lamented,73 the reports of Royal Commissions and the like can be looked at in order to fill in the legislative background. ${ }^{74}$ Legitimate sources of assistance would therefore include the Report of the Institute of Law Research and Reform on Matrimonial Property 75 as well as that of the Royal Commission on the Status of Women in Canada. ${ }^{76}$ Furthermore, the shortcoming itself is so notorious that a court searching for the offending mischief ought to be able to identify it with ease. Indeed, it is adverted to repeatedly in the Haldane and Wachtel judgments:

[The law of separate property was] inadequate to secure justice to the generality of married women, who have neither land, investments nor professional earnings . . . . Marriage had come to be regarded as a partnership of equals, even though the equal partners performed widely different functions.77

'The cock can feather the nest because he does not have to spend most of his time sitting on it.'78

'In the nature of things the wife's contribution to the family welfare has usually had a domestic rather than a money importance. ..." By performing her function of home-minder, the wife releases her husband to perform his function as breadwinner. So long as private property is regarded by society as an institution of social value (constituting a sphere within which the individual can make direct choices affecting his or her own life), a law that enables a husband to claim as his exclusive property all the bread left over from immediate consumption, while vouchsafing to the wife only whatever crumbs she managed to scrape together by her own fortuitous and rare economic activity supervening of her domestic duties, was denying pro tanto the concept of marriage as a partnership of free equals in which the partners performed complementary functions. ${ }^{79}$

In the generality of marriage the wife bears and rears the children and minds the home. She thereby frees her husband for his economic activities. Since it is her performance of her function which enables the husband to perform his, she is in justice entitled to share in its fruits.'

72. The Honourable James Foster, Alberta Hansard, May 16, 1978 at 1266.

73. See e.g., R. v. Kito Canada Ltd. [1976] 4 W.W.R. 189 (Man. C.A.) per O'Sullivan J.A. at 194; and "Hansard - Closed Book" 128 New L.J. 297 (March 30, 1978).

74. See e.g., Davis v. Johnson [1978] 1 All E.R. 1132 (H.L.) at 1157, per Lord Scarman: In Black-Clawson International Ltd. v. Papier-werke Waldhof-Aschaffenbury AG [ [1975] 1 All E.R. 810 (H.L.)] this House clarified the law on the use by the courts of travaux préparatories. Reports such as are prepared by the Law Commissions, by royal commissions, law reform bodies and select committees of either House which lead to legislation may be read by the courts to identify the mischief, including the weaknesses in the law, which the legislation is intended to remedy or reduce. The difficulty, however, remains that one cannot always be sure, without reference to proceedings in Parliament which is prohibited, that Parliament has assessed the mis. chief or understood the law in the same way as the reporting body. See also Firman v. Ellis [1978] 2 All E.R. 851 (C.A.) at 858, wherein Lord Denning endorsed the consideration of the Interim Report of the Orr Committee on Limitation of Actions in Personal Injury Claims (Law Reform Committee Twentieth Report, May 1974, Cmnd 5630) as part of the background of the Limitation Act 1975; and $R e$ Laidlaw and Municipality of Metropolitan Toronto [1978] 2 A.C.W.S. 68 in which the Supreme Court of Canada approved resort to the Report of the Ontario Law Reform Commission on Expropriation as an aid to the interpretation of the Expropriation Act subsequently passed.

75. Supra n. 24.

76. (1970) Information Canada (Chairman Florence Bird).

77. Haldane v. Haldane [1976] 2 N.Z.L.R. 715 at 721.

78. Wachtel v. Wachtel [1973] 1 All E.R. 829 at 837 quoting Sir Jocelyn Simon P.

79. Haldane v. Haldane [1976] 2 N.Z.L.R. 715 at 721 citing Woodhouse J. in Hofman v. Hofman [1965] N.Z.L.R. 795 at 798. 
But the courts have never been able to do justice to her. 80

The problem which so frequently presents itself on marriage breakdown is also well-described in the the Canadian case of Rathwell:81

In broad terms matrimonial property disputes are much alike, differing only in detail. Matrimonial property, i.e., property acquired during matrimony .... is ordinarily the subject matter of the conflict. One or other or both of the spouses may have contributed financially to the purchase. One or other may have contributed freely given labour. The contribution may have been direct or indirect in the sense of permitting the acquisition of an asset which would otherwise not have been acquired. Such an indirect contribution may have been in money or it may have been in other forms as, for example, through caring for the home and family. The property is acquired during a period when there is marital accord. When this gives way to discord, problems arise in respect of property division. There is seldom prior express agreement. There is rarely implied agreement or common intention, apart from the general intention of building a life together. It is not in the nature of things for young married people to contemplate the break-up of their marriage and the division, in that event, of assets acquired by common effort during wedlock.

Importantly, the shadow cast by the umbrella of Alberta's Matrimonial Property Act extends beyond the readily apparent evil of inequality in the property position of the homemaker wife to encompass the equitable sharing of property by spouses who have each pulled a fair share of the marriage load no matter what division of function with the matrimony they have chosen for themselves. In the ensuing discussion of sections 7 and 8 , the writer has employed the convenience of referring to husband and wife in their conventional marriage roles. Nevertheless, the reader should bear the broader scope of the Act constantly in mind.

\section{MEANING OF PROPERTY}

By section $7(1)$, the court is empowered to "make a distribution between the spouses of all the property owned by both spouses and by each of them." The word 'property' is not defined.

Courts in both England and Australia have wrestled with the issue of 'what is property' within the context of their respective matrimonial property sharing provisions. Frank Bates has examined the experiences in these two jurisdictions in a very useful article entitled "The Meaning of 'Property' in Family Property Disputes",82 the contents of which may be summarized as follows:

In England, resolution of the issue whether a tendency, either from a local council or by private contract, is 'property' within the terms of section 24 of the Matrimonial Causes Act $1973^{83}$ has turned on the assignability of the tenancy. If there is no covenant against assignment, either express or imputed, the tenancy is 'property' for purposes of the power to adjust ownership in proceedings for divorce, nullity or separation.

In Australia disputes have arisen over the interest created by a long term financial arrangement for the private purchase of a home

80. Wachtel v. Wachtel [1973] 1 All E.R. 829 at 838 again quoting Sir Jocelyn Simon P.

81. [1978] 2 W.W.R. 101 (S.C.C.) per Dickson J. at 107.

82. Bates, Frank, "The Meaning of 'Property' in the Family Property Disputes", 8 Fam. L. 24 (1978).

83. (U.K.), c. 18. 
offered by the state Housing Commission's bank which put it "simultaneously in agreement to sell and purchase, to let and be let into possession and to create a lessor and lessee". ${ }^{84}$ The trial judge, in the case of In the Marriage of Nelson, 85 regarded the words "whether in possession or reversion" in the relevant definition of 'property' as extending rather than limiting its meaning. In holding that the interest of the couple in their home created by transaction amounted to 'property' within the scope of the Act, he stated:86

The current English, by 'English' I mean 'English Australian' usage of the word 'property' includes in its meanings, and has been held in relation to other statutes to include things other than corporeal property, for example... such things as shares and choses in action and I do not exclude from 'property' as defined the interests parties have under a contract.

Shares owned by each party in a family company have also been the subject of dispute in Australia. The Full Court of the Family Court of Australia quoted the language of the Nelson judge with approval in In the Marriage of Duff 87 to hold that such shares "amounted to property within the meaning of s. 4 of the Family Law Act 1975".88 Having found it "unnecessary to set out a catalogue of what "property' may include," the court then, in Bate's words, "went on to adopt the definition enunciated by Langdale M.R. in Jones v. Skinner ${ }^{89}$ that, 'Property is the most comprehensive of all terms which can be used inasmuch as it is indicative and descriptive of every possible interest which the party can have." "90

A British Columbia judge had occasion to comment on the meaning of 'property' under section 8 of that province's Family Relations Act'1 in the case of Jensen v. Jensen.92 It did not appear to him that the word 'property' as used in that section was "necessarily confined to real property or to any particular property, although undoubtedly it does include [the] matrimonial home". .93

The treatment of shares and other business assets has given rise to litigation in Saskatchewan. As amended in 1974-5, section 22(3) of the Married Women's (now the Married Persons') Property Act. empowers the court to make a sharing order between the spouses "notwithstanding that the legal or equitable interest of the husband

84. Bates, supra n. 82 at 25.

85. (1977) F.L.C. 76, 067.

86. Id. In the earlier case of In the Marriage of Komaroni, (1976) F.L.C. 75, 695, another judge had held that the property sharing section was restricted to corporeal property to which a party had the immediate right to possession or a claim in reversion, so as to include choses in possession but not mere choses in action.

87. (1977) F.L.C. 76, 127.

88. Id. at 76,133 .

89. (1835) 5 L.J. Ch. 90.

90. Bates, supra n. 82.

91. S.B.C. 1972 , c. 20 , s. 8 .

92. (1976) 29 R.F.L. 319.

93. Id. at 331 .

94. R.S.S. 1965 , c. 340 s. 22 as am. S.S. $1974-75$, c. 29 and thereafter. 
or wife in the property is in any other way defined."95 According to one writer, ${ }^{96}$ the Saskatchewan language contemplates the inclusion of a business which holds substantial assets within the 'property' available for sharing. Of the cases, he says:97

\begin{abstract}
In Koshman v. Koshman ${ }^{98}$ the business was a sole proprietorship and no problems arose, but in five cases, some or all of the assets were held by a compnay. In two of these cases ${ }^{90}$ the wife was ordered to transfer her share(s) to the husband in return for certain property In the third, Boardman v. Boardmanion two houses owned by the husband's company were ordered transferred to the wife. Mr. Justice Hughes indicated that this would not have been possible were not the husband the sole shareholder. In the last two cases, all assets were held by companies. In Lindberg v. Lindberg'o1 the late Mr. Chief Justice Bence refused to deal with the assets of the company, and did not alter the number of shares held by each spouse. He then ordered the winding up of the company as an agreement could not be reached. On the other hand, Mr. Justice Hohnson (as he then was) in Boucher v. Boucher ${ }^{102}$ saw no impediment to dividing the assets of the company between the parties. Perhaps Mr. Chief Justice Bence's reluctance to speak in terms of assets arose from a felling on his part that the shared distribution of $600-400$ in the husband's favour was fair and equitable, whereas, in Boucher, the wife held but one share to the husband's ninety. nine and a variation in the shared distribution would have been meerely one more step to the ultimate result of equal division. Both approaches, then, would appear to be acceptable and either could be used as the circumstances demanded.
\end{abstract}

Query whether the powers of the court are truly broad enough to permit an order to wind up a company which, of course, cannot be a party to a marriage!

The meaning to be attributed to word 'property' takes on significance for two purposes. The first has to do with the ambit of property which may be taken into account in calculating the shareable wealth of each spouse for the purpose of determining the proportions of property to which each ought to be entitled. The second relates to the particular property and manner selected by the court to give effect to those proportions. The court is able, for the latter purpose, to choose from among the wide variety of powers conferred on it by section 9: the order may be for the payment of money or transfer of an interest in property, or for the sale of property and division of proceeds, or for a declaration of an interest in property where none exists at law or in equity;103 the payment of money may be spread over time with or without interest, a spouse may be required to give security, property

95. Section $9(2)(c)$ of the Alberta Act is to the same effect. It empowers the court to declare "that a spouse has an interest in property notwithstanding that the spouse in whose favour the order is made has no legal or equitable interest in the property."

96. Ron W. Hewitt, "Section 22: The Marrried Women's Property Act," (1978) 42 Sask L. Rev. 260. This article reviews all written judgments, both reported and unreported, made in the Saskatchewan Court of Queen's Bench between May 1, 1975, when section 22(3) of the Married Women's Property Act was proclaimed in force, and October 6. 1977.

97. Id. at 265-6.

98. (1976) 27 R.F.L. 249 (Sask. Q.B.).

99. Edwards v. Edwards, unreported decision of Hughes J., Nov. 26, 1976 (Sask. Q.B.) and Collins v. Collins, unreported decision of MacDonald J., June 15, 1977 (Sask. Q.B.).

100. Unreported decision of Hughes J., July 18, 1977 (Sask. Q.B.).

101. (1976) 30 R.F.L. 180 (Sask. Q.B.)

102. Unreported decision of Johnson J., Jan. 27, 1977 (Sask. Q.B.).

103. S. 9(2). 
may be charged, conditions (including the release of dower rights) laid down, a trust imposed, variation granted, a joint tenancy severed and anything else that the court considers necessary done; 104 and where part of the property of the spouses is situated outside Alberta, the court may resort to property within the province in order to ensure compliance with its distribution. 105

Notwithstanding the problem posed by unassignable interests, a wide purview of property seems most appropriate for purposes both of apportionment and of actual distribution. Where, as in the case of a right of action for damages for pain and suffering caused by a third party's negligence, the right is so personal as to have nothing whatsoever to do with the matrimony, the Act itself directs specific exemptions. 106 When it comes to effecting a distribution of shares in a private company the ownership of which may be transferred only with the approval of the directors, or to dealing with property which is subject to a covenant with a third party, the court may be expected to do as much as it can to avoid interfering with the economic viability of a business enterprise and existing interests of third parties in property. To this end, it is open to the court to exercise its powers under section 9 in an imaginative fashion as courts in other jurisdictions have done. For example, in the Ontario case of Weir v. Weir, ${ }^{107}$ the wife's entitlement to a 25 per cent share of the business assets was met out of the family rather than the non-family assets, this being more desirable in the circumstances of the case. In the British Columbia case of Deleeuw v. Deleeuw, 108 the wife was persuaded by the practical limitations on the realization of shares in a family company, should the court order their transfer to her from the husband, to accept a lump sum payment for maintenance in its stead. Another British Columbia case, Mar v. Mar, ${ }^{109}$ suggests the potential for creative use of trust provisions. 110 There, a conveyance of the home was not ordered in the circumstances, but the husband was declared to hold a one-half interest in trust for the wife.111

\section{CATEGORIES OF PROPERTY}

Section 7 isolates three categories of property: property not exempt in itself but in respect of which a money value is exempt from sharing; ${ }^{112}$ gains and acquisitions which are shareable but without any presumption of equality;113 and property which is shareable equally in the dis-

104. S. $9(3)$.

105. S. $9(1)$.

106. See e.g., s. 7(2)(d).

107. [1978] 2 A.C.W.S. 441.

108. (1977), 82 D.L.R. (3d) 522 (B.C.C.A.).

109. [1978] 3 A.C.W.S. 7.

110. S. $9(3)(g)$ of the Alberta Act empowers the court to "impose a trust in favour of a spouse with respect to an interest in property."

111. The above discussion has proceeded on the assumption that the word "property" is meant to be applied affirmatively. As to the sharing of losses, see heading IX.F below.

112. S. 7(2).

113. S. 7(3). 
cretion of the court.114 In distributing property which is shareable in either unspecified or equal proportions, the court must consider the criteria itemized in section 8.115

\section{A. Exemptions}

Under section 7(2), the market value, measured either at the time of marriage or date of acquisition, of certain property is exempt altogether from sharing. The exempted amounts relate to property toward which the other spouse customarily will not have contributed during marriage: gifts from third parties, inheritances, property brought into the marriage, tort recoveries of a personal nature, and insurance proceeds which are not in respect of property and do not compensate for a loss to both spouses.

\section{B. Sharing in Unspecified Proportions}

Section $7(3)$ covers property toward which the contribution of the other spouse or the basis for his claim to an interest will not be instantly apparent for many marriages. The court is directed to distribute property which falls into this category "in such manner as it considers just and equitable" but without a starting presumption of equal sharing. The subsection embraces gains in, or property substituted for, or proceeds of disposition of exempt property; property acquired after divorce, nullity or judicial separation; and gifts from the other spouse.

\section{Equal Sharing}

Section 7(4) - the main distribution provision - encompasses property not caught by the previous two subsections. This subsection rests on the assumption that in the circumstances of an ordinary marriage the combined efforts of both spouses will have been responsible for the accumulation of all such remaining property which the court is instructed to divide "equally between the spouses unless it appears ... that it would not be just and equitable to do so".

\section{COMPLEXITIES OF CATEGORIZATION}

Categorization for purposes of the application of section 7 appears to be mandatory by virtue of the absence of any presumption that "all the property owned by both spouses and by each of them" is shareable unless and until it is shown to qualify for exemption under subsection (2) or special treatment under subsection (3).

The Legislature's decision to categorize may prove unfortunate. Section 7 accomplishes a salutary degree of certainty that some wealth will be protected from sharing (it is likely that the courts themselves would have excluded such items from sharing in a usual case), and that certain other property will receive differential treatment (section $7(3)$ eliminates any notion of automatic sharing for property within its classification). But the price of that certainty is complexity - a complexity coupled, ironically, with ambiguity or uncertainty as to the result intended by the Legislature on some facts. The intermingling

114. S. 7(4).

115. These criteria are discussed more fully under heading $X$. 
of references to property in kind and to its dollar value at one or another point in time produces further confusion. This appears to be a result of mixing the concept of deferred sharing, which is concerned only in valuated amounts, with judicial discretion which enables the court to deal directly with property.

Six particular complications of categorization are discussed below. Of these, the most worrisome is its impact on proof.

\section{A. Onus of Proof}

Each of the three categories of property appears to convey its own demands for proof. It is likely that a spouse's entitlement to a share in property coming within the scope of section $7(3)$ must be proven by the spouse so claiming. The 1963 New Zealand legislation'16 did not specifically state who should have the onus of proof, nor did it provide for the court to have regard to the respective contributions of the husband and wife to the property in dispute. The New Zealand Court of Appeal held, in $E$. v. $E$., 117 that the claimant "must accept the burden of proving in a reasonable manner the nature of the contributions she made to one or more particular properties".118 Of course, under the Alberta statute contribution ranks among the several matters enumerated in section 8 which the court is to consider in making an order. But this distinction does not destroy the force of the argument that where, as under section $7(3)$, there is no presumption of the equal division of property, the onus is on the claimant to prove entitlement to a share.

The opposite holds true of property governed by section 7(4). Here, notwithstanding that the language of presumption is not particularly strong, the opening direction to distribute property equally between the spouses shifts the onus of showing that equal sharing is not just and equitable to the party trying to obtain, or keep, more than half.

That leaves the question of exemptions. The language of section $7(2)$ is absolute: if the property fits the description, its market value at the relevant prior time is exempted. Is it the responsibility of the party applying for a matrimonial property order to demonstrate that the property in respect of which a share is claimed is not the sort which is subject to exemption? Or, must the party seeking the exemption adduce the proof? The court might even be under a duty to satisfy itself that the property sought to be distributed does not fall within section $7(2)$. Considering the reasonableness and practicality of each of these possibilities, it is submitted that the party wishing to take advantage of his entitlement to an exemption should bear the onus of proving that the property qualifies for it.

The contrasting onuses of proof applicable to shareable property will have serious ramifications for the weighting of contribution and the other matters named in section 8 because the court will be obliged to approach the question of sharing from two different directions. The result under each of subsections (3) and (4) of section 7 will

116. Matrimonial Property Act 1963 (No. 72 of 1973).

117. [1971] N.Z.L.R. 859.

118. Id. at 884 per North P. 
depend most significantly on the strength which the court attaches to the onus and on the credit it accords to the key section 8 factor, that being the work of the spouse in the home.

Assessments of the actual experience under legislation granting a judicial discretion to distribute property in unspecified proportions vary. The "Statement on Matrimonial Property Laws in Canada" published by the federal Advisory Council on the Status of Women in January 1978 expresses dissatisfaction with the value which the courts are placing on this work relative to work outside the home in the provinces of British Columbia and Saskatchewan where, as has been seen, a judicial discretion to adjust property interests has been introduced by statute.119 The observations of a Saskatchewan writer stand in contrast. Ron W. Hewitt 120 saw a tendency in the Court of Queen's Bench judgments which he reviewed for judges to divide property equally: "The amount of an award under s. 22 varies considerably but an even division is fairly common." 121

In one of the first reported decisions on the Ontario legislation ${ }^{122}$ which came into force on 31 March 1978 (under which the discretion to divide property that is not a family asset is exceptional), the Court recognized the value of the wife's assumption of the major share of child care and household management as enabling the husband to devote more of his time to working in his business than would have been possible otherwise. The wife was awarded not a half but a onequarter interest in her husband's property investment.123 A like disposition occured in the subsequent case of Weir v. Weir. ${ }^{124}$

With Rathwell,125 in particular, efforts of the judiciary to effect a more even sharing of matrimonial assets under the exisiting law have become clearly discernible. Now that the crucial factor - the contribution of the spouse in the home - has been cited by statute for consideration, may we not expect the present tendency toward equal sharing to expand? 126

For property subject to the presumption of equal sharing, the question changes to: how readily will the courts depart from equal sharing by virtue of a finding that it would not be just and equitable? As one writer asked of the possibility of exception to the equal division of family assets when the Ontario scheme was at the Bill stage:127

119. Family Relations Act, S.B.C. 1972, c. 20, s. 8; Married Women's Property Act, R.S.S. 1965 , c. 340 , s. 22 as am. S.S. $1974-75$, c. 29 and thereafter.

120. Supra n. 96.

121. Id. at 271.

122. Family Law Reform Act, 1978, S.0. 1978, c. 2.

123. Silverstein v. Silverstein (1978) 1 R.F.L. (2d) 239 (Ont. S.C. [Family Law Division] ).

124. [1978] 2 A.C.W.S. 441. In England, the Wachtel court adopted, as a flexible starting point from which to decide what share ought to be awarded to the spouse claiming financial provision, a guide of one-third of the combined resources of the couple: see Wachtel v. Wachtel [1973] 1 All E.R. 829 (C.A.) at 839-40. There, following the precedent set in the ecclesiastical courts, a starting point of one-third of the joint incomes of the husband and wife had been used by the divorce courts in assessing maintenance.

125. [1978] 2 W.W.R. 101.

126. For further discussion of the ramifications of naming this factor, see heading $\mathrm{X}$ below.

127. Winnifred H. Holland, "Reform of Matrimonial Property Law in Ontario" (1978) 1 Can. J.F.L. 4 at 25. 
Will [the courts] regard equal division as the norm, to be disregarded only under very unusual circumstances, thereby setting a heavy onus for any request for deviation? Hopefully, the courts will adopt such a view, but it might well have been preferable to spell this out in the legislation.

The 1976 New Zealand Act128 provides for equal sharing of the matrimonial home and household chattels except "[w]here there are extraordinary circumstances that, in the opinion of the Court, render [equal sharing] repugnant to justice". $129 \mathrm{~A}$ New Zealand commentator submits that this "is the section of the new legislation that is most likely to lead to uncertainty and litigation".130 At the same time, he hopes "that the Courts will be slow to allow exceptions and be ever mindful of the purpose of the Act and of the concept of marriage as a partnership of equals".131

The same hope may be expressed for Alberta, although if the experience elsewhere in Canada leads judges to take a lesser view of the work of the spouse in the home than of outside contributions, we may see frequent deviation from the equal sharing starting point.

\section{B. Ascertainment of Existing Interests}

The ascertainment of existing property rights and interests is a logical prerequisite to the making of an order distributing those interests. Categorization is not the cause of this prerequisite; however, the diverse consequences of categorization - whereby property may be exempt as to an evaluated amount, or it may fall within one of two different sharing presumptions - does render such advance determination the more imperative. The practical importance of the prior clarification of existing interests may be highlighted by an example. Suppose that one spouse, the husband, claims an exemption in respect of the market value of the home he owned before marriage. The wife, who had been living with him at the time, asserts that by reason of her contribution either in money or money's worth to the home she had earned a beneficial interest in it. If the issue of entitlement to the beneficial interest is not resolved before distribution under the Act the wife will suffer double jeopardy: not only will she have lost the exemption to the extent of the value of the beneficial interest which she should have been granted because she brought that interest with her into the marriage, but also the husband, whose exemption should have been reduced by the same amount, will be credited with it instead.

Where all the property to be distributed falls within the equal sharing provision of section 7(4), the precise ascertainment of the spouse's proprietary interests is of arguably less significance, albeit that the spouses may not welcome a gratuitous juggling of the ownership of

128. Matrimonial Property Act, 1976, (No. 166 of 1976).

129. Id. s. 14. The phrase "repugnant to justice" comes from Wachtel v. Wachtel [1973] 1 All E.R. 829.

130. W.R. Atkin, "The Regime of Family Property Law" (March, 1977) N.Z.L.R. 81.

131. Id. 
their property. Playing with the facts of an Ontario case,132 imagine the spouses' surprise if, quite unsolicited, in a dispute over the distribution of all property acquired by the couple during the marriage the wife were to be awarded the husband's prize hunting trophies and the husband were to end up with her antique doll collection.

Australian jurisprudence bears out the conclusion that the court must pay initial regard to the legal and beneficial rights of the spouses to property. There, as previously indicated,133 section 86 of the Commonwealth Matrimonial Causes Act $1959{ }^{134}$ gave the divorce court a discretion to make a "just and equitable" settlement of the property of the spouses, whereas section 17 of the same Act set up a procedure for the declaration of existing rights. In face of the argument that the relief sought under each of these sections was fundamentally different, the persistently better view was that "even under section 86 it [was] necessary for a court to know the precise proprietary interests of the parties before it [could] readjust them".135

By nullifying the presumption of advancement for purposes of a matrimonial property order, section $36(1)$ plays a part in the ascertainment of proprietary interests: in the case of a husband's uncertain intention to make a gift to his wife, equity presumes in the wife's favour; under the Act, ownership remains with the purported donor. ${ }^{136}$ Subsection (2) is also relevant to the determination of existing interests: it provides in paragraph $(a)$ for a presumption of intention to confer joint ownership. Moreover, under paragraph (b), where money is deposited in a financial institution in the names of both spouses it is deemed to have been done so by the spouses as joint owners so as to give rise to the presumption of intended joint ownership. The Act

132. Boydell v. Boydell (1978) 2 R.F.L. (2d) 121 (Ont. Unified Fam. Ct.), in which the husband's claim under the Ontario Family Law Reform Act, 1978 to an interest in his wife's doll collection, of substantial value, was denied. The husband did receive an order for a monetary payment in compensation for his contributions to the collection, which included driving his wife on doll-buying trips and building doll cabinets.

133. See heading V.B. above.

134. No. 104 of 1959.

135. Turner, supra n. 57 at 403, citing Smee v. Smee (1965) 7 F.L.R. 321 at 334, per Walsh J. (N.S.W.): Anderson v. Anderson (1972) 19 F.L.R. 480 (Joske J., A.C.T.); cf. Sanders v. Sanders (1967) 116 C.L.R. $\$ 66$ (High Ct. of Australia).

136. Query whether this shift in the evidentiary burden would have operated to avert the result in either the British Columbia case of Feaver v. Feaver (1977) 1 R.F.L. (2d) 108 (B.C.S.C.) or the Supreme Court of Canada decision in Bingeman v. McLaughlin [1978] 1 S.C.R. 548. That is to say, would the weight of evidence which is adequate to uphold the presumption of advancement under the existing law also be sufficient to rebut the presumption of resulting trust which (in the absence of evidence of actual intention) will apply in its stead by reason of section $36(1)$ of the Matrimonial Property Act? In Feaver the husband claimed a one-half interest in shares purchased, with his concurrence, in his wife's name out of monies from a chequing account used by both spouses. In giving effect to the presumption of gift, the Court seemed to be impressed by the fact that the shares were purchased on the advice of the wife's father and that the wife's contribution to the account was greater than, and her financial position generally superior to, that of the husband. In Bingeman v. McLaughlin the husband sought the restoration of the joint interest in the family farm which we had conveyed to his wife. In rejecting the suggestion that the husband's true intention was to protect the property from potential creditors, the Court looked upon the laspe of time combined with other occurrences between conveyance and claim as evidence verifying the presumption of advancement. 
is silent as to the extent of the interest of each joint owner arising from the presumption thereby created. Apart from the operation of this section, the presumption of advancement and the law of joint ownership remain unimpaired; nor is section $7(3)(d)$ affected by the applicability of the presumption of advancement, for that subsection subsumes uncontroverted gifts.

Quite apart from categorization, section 17 may influence the relationship between the provisions of the Matrimonial Property Act and the determination of existing interests. Subsection (1) permits a question respecting property which arises between spouses in any other matrimonial cause to be decided as if it has been raised in proceedings under Part 1 of the Act. Subsection (2) provides further that if the court feels it necessary to have other matters determined first or at the same time it may adjourn the application for a matrimonial property order until that is done. Where the separation or breakdown criteria upon which jurisdiction under this Act is founded have not been satisfied, it is a neat point whether a property question raised in another matrimonial cause may be resolved in accordance with its provisions for matrimonial property sharing or whether the principles of separation of property shall apply. The question is particularly interesting when one observes that a "matrimonial cause" presumably includes a petition for the restitution of conjugal rights which, although it may follow upon a period of separation, nevertheless amounts to an affirmation of the continuance of the marriage and not of its admitted failure.

\section{Artificiality}

The decision to categorize has forced the Legislature to make arbitrary choices and to risk the anomalous consequences of those choices. Some examples follow.

To begin with, as pointed out in the preceding discussion of the ascertainment of existing interests, the exclusion from sharing of property acquired by a spouse before marriage means that contributions made during a period of cohabitation prior to the marriage lie outside the discretion granted by the Act. The cohabitee must fall back on the proprietary approach of the present law in the hope of proving the creation of a beneficial interest in the property during this time period. A New Zealand writer has remarked upon a similar consequence under the 1976 enactment in that country:137

... a couple who live together in a de facto relationship with the intention of eventually marrying and who acquire property during this time, may well not see that property becoming matrimonial property ... should they in fact marry.

A married spouse may be caught in a similar bind. It is not uncommon in rural Alberta for a couple to live on, work and build up a farm owned by the aging parents of one of them in the vague expectation that the farm will eventually be handed on by gift or inheritance. Indeed, they may do so at the parents' urging. ${ }^{138}$ Assume that such a

137. Atkin, supra n. 130 at 82 . For the Saskachewan experience under a more general contribution-based discretion see Hewitt, supra n. 96 at 268.

138. This illustration was brought to the writer's attention by Jean McBean, an Edmonton practitioner. 
farm is owned by the wife's parents. Subsection $7(2)$ will favour her with an exemption of the market value of the farm when it is acquired irrespective of the husband's joint contribution to it over the years. Had the couple gone out and purchased a farm at the outset of their marriage, and had they both worked as hard to develop that property, the husband would have enjoyed the benefit of a presumption of equal sharing when the marriage later broke down. Since that is not the situation, he will instead be faced with the obstacle of establishing his entitlement, based on his past labours, to a beneficial interest in the farm at the time of its inheritance by his wife. ${ }^{139}$

An exemption may also operate to denude a gift from one spouse to the other. Suppose that a husband gives his wife a precious work of art which he purchased before marriage. Under the Act, the wife will acquire title to the gifted property. However, by virtue of section $7(2)(c)$, the husband may claim an exemption in the amount of its value when the couple were married. If that value has remained constant, the Act will have operated to reduce the gift to its sentimental essence, for the wife will have the painting but the husband will have its dollar value.

An anomalous result may also flow from a gift between spouses of property acquired after marriage to which no exemption attaches. A donor husband may have been motivated by a surge of love and affection to make a gift to his wife or, a possibility addressed by the Supreme Court of Canada in Bingeman v. McLaughlin,140 his motive may have been the less honourable one of defeating creditors. In either case, he will bear the full burden of proof that he ought to be entitled to share in the property because of its categorization within section $7(3)(d)$.

Because categorization is compulsory, circumstances which are similar in kind may operate as a mere factor for consideration on one set of facts and as a rigid ground of categorization on another. For example, property acquired when the spouses are living separate and apart is shareable in equal proportions unless the acquiring spouse demonstrates that it would be unjust and inequitable for the other spouse to share in it. The time of its acquisition is merely a matter for consideration. ${ }^{141}$ In contrast, the acquisition of property after divorce, nullity or judicial separation places it within section $7(3)(c)$ and puts the full onus of proving entitlement to a share on the non-acquiring spouse.

\section{Record-Keeping}

The task of separating property into correct categories suggests the advisability of maintaining an accurate record from the outset of marriage. Keeping such an account is rendered the more prudent by

139. Note that the exemption in section $7(2)(b)$ of property acquired by inheritance is not restricted to inheritances from third parties. If it is read to include an inheritance from a deceased spouse, the according of an exemption will conflict with the direction in section $11(3)$ that a court making a matrimonial property order in favour of the surviving spouse of a broken marriage "shall take into consideration any benefit received by the surviving spouse as a result of the death of the deceased spouse."

140. [1978] 1 S.C.R. 548.

141. See s. $8(f)$. 
section 31 which minimizes the possibility of undisclosed assets by obliging each spouse to prepare "a statement, verified by oath, disclosing particulars of all the property of that spouse" 142 including particulars of property disposed of within one year before the commencement of proceedings under Part 1 of the Act. ${ }^{43} \mathrm{~A}$ form of statement is to be prescribed by the regulations, 144 and it is likely to demand that information be given in considerable detail.145 A comprehensive record, therefore, should track the nature of each asset, its date and manner of acquisition, its market value at that time, its source, and its subsequent history - sale or disposition, and use of proceeds for substitution or other purposes.

\section{E. Valuation}

For an exemption to be awarded in respect of property falling within section $7(2)$, a past value of that property - its market value at the later of the time of marriage or the date of its acquisition must be established. The same prior valuation is necessary to determine the extent of property subject to unequal sharing under section $7(3)(a)$ - in this instance, the difference between the earlier valuation and the value at the time of the trial either of the property which originally qualified for exemption or of property thereafter substituted for it. Not only do practical limitations attend the obtaining of backdated valuations, but also it is feasible that the form of statement of particulars made mandatory by section 31 will designate market values as part of the information which each spouse must supply about his own property - considerations which further sustain the usefulness of a good set of records.

The Act does not pinpoint the time for valuation of property caught by the remaining paragraphs of section $7(3)$, nor of property encompassed by section 7(4). In New Zealand section 2(2) of the 1976 Act146 specifies assessment at the time of the hearing, in contrast with such possible alternatives as the date of separation, or of filing of the aplication. The court is also empowered to order a different date. Absent designation in the Alberta statute, the selection of the appropriate date for valuation would appear to be a matter for the discretion of the court in the application of the sharing principles. 147

Unless accurate assessments are introduced in evidence, courts will be hard-pressed to make "just and equitable" orders. This could be a problem if the Alberta practice grows to resemble that in Saskatchewan. There, at least one judge has remarked upon "the difficulty of reaching a fair conclusion when rarely is a proper valuation of the property presented by either party".148

142. S. 31(1).

143. S. 31(2).

144. S. 31(3).

145. See J.C. Soby, "Jurisdictions, Limitations, Forms and precedents" at 8-11: (1978) Legal Education Society of Alberta, Matrimonial Property Practice - The New Deal.

146. Matrimonial Property Act 1976 (No. 166 of 1976).

147. Note, however, that where recourse is had under section 10 in respect of a gift, or of a transfer to a mala fides third party, the property will receive its value at the time of the trial.

148. Keeler v. Keeler, unreported decision of MacPherson J., March 10, 1977 (Sask. Q.B.) cited in Hewitt, supra n. 96 at 271. 


\section{F. Sharing of Losses}

The Matrimonial Property Act does not appear to countenance the sharing of the debts of a spouse whose total asset position is a negative one at the time of distribution. Used in its ordinary sense, the word 'property' imports an affirmative connotation such that it may embrace debts owed to a spouse but exclude those owed by him which reduce his belongings to less than nothing.

The language of section $7(3)(a)$, however, raises the possibility that at least some losses may be shareable. It describes the difference between the value of an exemption attributed to a piece of property under section $7(2)$ and the market value of the same property or of property substituted for it, either in exchange or acquired with the proceeds of its disposition, at the time of the trial. During inflationary times, as at present, that difference ordinarily will be incremental. But during a period of declining market values the difference could comprise a loss.

If a loss is shareable the onus of proof under section 7(3) will take a peculiar shift from the non-owner spouse who is claiming a share in the distribution of the property to the owner spouse who will be striving to show that the non-owning spouse should bear a part of the loss.

\section{GUIDING FACTORS}

\section{A. General Considerations}

Section 8 itemizes thirteen matters for consideration by the court in making a distribution of matrimonial property under section 7. As previously mentioned, section 7(3) makes attention to these factors a prerequisite to the determination of what is just and equitable. Subsection (4) - which contemplates an equal distribution unless it would not be just and equitable, having regard to these criteria - also seems to anticipate their consideration prior to order. Competent counsel, it may be expected, will prepare to address each of these matters in their presentations to the court.

The provisions of section 7(3) and (4) suggest an issue preliminary to discussion of the thirteen criteria, and that is: in the final analysis, does the "just and equitable" directive sustain an overall discretion, or is the result reached by a weighing of the enumerated factors decisive? The answer appears to flow from the inclusion in paragraph $8(m)$ of "any fact or circumstance that is relevant." The introduction under this head of matters peculiar to the case at hand will tend to tip the balance of the weighing scales in the direction of what is just and equitable. But beyond this, as Lord Denning asserted in the Wachtel case which involved decision consequent upon the application of legislatively enumerated factors not unlike our own:149

In all these cases it is necessary at the end to view the situation broadly and see if the propo. sals meet the justice of the case.

149. [1973] 1 All E.R. 829 (C.A.) at 842. This is more obviously so under the open discretion granted by section 8 of the British Columbia Family Relations Act, as indicated by the decision of Hawrysh v. Hawrysh [1978] 2 A.C.W.S. 233 wherein it was held that the court must look to all circumstances surrounding the acquisition of the property and of the marriage. 
The sequence, then, for purposes of a distribution under either section $7(3)$ or (4), will be first to consider the matters set out in section 8 including paragraph $(\mathrm{m})$ and then to take a broad view to ensure that the end result meets the demands of justice. 130

A second introductory question revolves around the need for contribution: is the foundation for sharing established by the fact of marriage alone, or does the Act rest on proof of an earned claim? The Privy Council addressed this issue in Haldane. 151 It regarded contribution as a jurisdictionally limiting factor under the 1963 New Zealand Act,152 explicitly rejecting the notion that the Act instituted any sort of formal regime of community of property. However, the contribution required was minimal and could be supplied by "the usual domestic contributions of an ordinary housewife, and not only [by] the contributions of a thrifty and frugal one".153

In Alberta, the question would seem to have been answered by the creation of exemptions in respect of property to which a spouse usually would not have contributed at all, leaving a presumption of minimal contribution intact for the purpose of the sharing provisions. Of course, the presumption of equal sharing might be displaced by a showing of no contribution, or the proportion of sharing altered by proof of very little contribution. Outcomes under the presumption of unequal sharing likewise would be affected.

A third preliminary point concerns the conceptual view which is taken of contribution, the factor under which the crucial weighing of the relative claims of each spouse to a share in matrimonial property will depend. The Act, as has been seen, is aimed at curing a present ill - the failure of the existing law to recognize the "contribution" rendered by a wife who fulfils an ordinary domestic role. Bearing in mind this purpose, and the fact that the asset position even of an income earning wife will usually be weaker than that of her husband, the political sensitivity of the negative side of contribution is not surprising.

Contribution may be viewed from one of two perspectives. Seen in its broadest form, it embraces behaviour and activity which conduces to the health of the marriage and the emotional and physical well-being of the family as a whole - the element responsible for a warm, loving home. Looked at in narrower focus, contribution may be confined to the economic sphere. Here the measurement may be of efforts which help the general financial position of the couple or family, or it may be of those which lead to the acquisition or enhancement of individual assets.

Each of these perspectives assumes another, less popularly discussed complexion when viewed in a negative light. Regarded in the broad sense, the obverse of contribution becomes marital misconduct, that is, behaviour which is detrimental to the marriage and the family

150. More extensive attention is paid to paragraph $(m)$ under heading X.B $(m)$ below.

151. [1976] 2 N.Z.L.R. 715.

152. Matrimonial Property Act 1963 (No. 72 of 1963).

153. Haldane v. Haldane [1976] 2 N.Z.L.R. 715 at 723. 
and which may be so intolerable as to cause its destruction. Taken in its narrower circumference, it will embrace conduct having a detrimental effect on the spouses' economic positions, and may include bad business judgment as well as outright dissipation.

The difficulty of fixing standards to be applied to the measurement of contribution in both its positive and negative aspects is complicated by the contrasting onuses of proof which flow from its categorization as shareable in presumptively equal or unequal proportions, a complication discussed earlier.154 Elaborating further, the question of deviation from a presumption of equal sharing may be framed in terms either of the extent of departure from the contribution which would ordinarily be expected, or of the degree of marital or economic misconduct required to displace the presumption. Where property is shareable in undesignated proportions, the claimant will be required to demonstrate positively his contribution, but will it be enough to show contribution to the marriage and the family in the wide sense, or must the contribution have an economic characteristic?

A more detailed examination of the treatment given to the contributions of the spouses, and to the other matters listed in section 8 , follows in the ensuing paragraphs. Detrimental economic conduct receives further attention in conjunction with the discussion of paragraphs $(a),(b),(c)$, and (1). The relevance of marital misconduct is addressed under paragraph $(m)$.

B. Section 8

(a) Contribution to marriage and family;

(b) Contribution to business or farm; and

(c) Contribution to property.

Paragraph $8(a)$ elevates the by now much vaunted work done by the spouse in the home to a matter worthy of consideration in substantiation of a claim to a division of matrimonial property - thereby according it the recognition which the courts, manoeuvring within the confines of the existing law, have been so reluctant to extend to it.

Its value having been acknowledged, how should the domestic contribution be measured - by some general standard or on an "asset by asset" basis? (The "asset by asset" approach is taken under the existing law when the court considers whether a spouse's contribution to specific property is sufficient to create a beneficial interest in that property.) In Haldane, the Privy Council concluded that the "asset by asset" approach was unjustified, being incompatible with the proposition that the performance of an ordinary housewife acting in her domestic sphere constitutes a contribution to the accumulation of assets adequate to entitle her to share in the property acquired.155 A similar result has been reached in Saskatchewan, where it has been held that the work done by the wife in the home or on the farm "need

154. See heading IX.A.

155. [1976] 2 N.Z.L.R. 715 at 727. 
not be above and beyond that done by the normal Saskatchewan housewife or farmwife".156

In special circumstances, even less may be required:137

[I]n Procknow v. Procknowiss the wife's work in caring for the home and family and doing farm chores to the best of her ability were considered a contribution despite the fact that her allergies and lack of mechanical ability did not permit her to perform many of the tasks and give as much assistance to her husband as most housewives do in Saskatchewan.

The fact that the contribution of the homemaker or parent is included for consideration does not automatically attribute to it a weight equal to that of the financial contribution of a spouse working outside the home. Although the contribution of a spouse as homemaker was put in paragraph $(a)$ to give it prominence, 159 it remains but one of thirteen factors none of which receives special rank or weight.

Also of relevance to the interpretation of paragraph $8(a)$ of the Alberta Act are the holdings in two Saskatchewan cases. The first such case is Rusnak v. Rusnak. 160 There, in the course of granting an application by the wife for a one-half interest in, sale, and division of proceeds of lands registered in the name of the husband, $\mathrm{Mr}$. Justice Disbery rejected her argument that giving birth to four children constituted a contribution on her part. To the contrary, he observed that: 161

... childbirth with its consequent expense depletes rather than contributes to the financial resources of the spouses. To hold such to be a "contribution" would simply open the door to ingenious counsel for respondent husbands in appropriate circumstances to raise the provisions of The Contributory Negligence Act . . . and claim a set-off against the applicant wife.

Because section 22(4) of the Saskatchewan legislation 162 specifically describes "caring for the home and family" as a form of contribution, these comments would appear to be confined to the feat of childbirth itself. It is difficult to make much sense out of this look in isolation at the act of giving birth. After all, conception - and hence childbirth is a natural consequence of normal marital relations. Although a partner who does not desire children may take precautions to avoid conception, where pregnancy does occur, it would seem more appropriate to regard having children as an event which, together with its inevitable influence on the division of labour within the marriage, has been accepted by the couple as enuring to their mutual benefit.

In the second case, Lauder v. Lauder, Mr. Justice MacPherson held that the phrase "caring for the home and family" must mean the whole family, and further that it "connotes more than the physical functions

156. Hewitt, supra n. 96 at 266-7. See also Galbraith v. Galbraith [1978] 2 A.C.W.S. 250 wherein, after 35 years of marriage, a wife sho was lacking in mechanical talent and had played no part in the family business nevertheless was awarded a one-third interest in it by reason of her contribution on the home front.

157. Hewitt, supra n. 96 at 267.

158. Unreported decision of MacDonald J., Nov. 10, 1975 (Sask. Q.B.).

159. Alberta Hansard, May 16, 1978 at 1266 per the Honourable James Foster.

160. [1976] 4 W.W.R. 515.

161. Id. at 521.

162. Married Women's Property Act, R.S.S. 1965, c. 340, s. 22 as am. S.S. 1974-75, c. 29 and thereafter. Compare "contribution made as a homemaker or parent" in the Alberta section. 
of preparing meals and cleaning the residence". ${ }^{163}$ The decision was a hard one on the facts, for Mrs. Lauder's excessive devotion to the care of a severely retarded child of the marriage over the last eight or nine of the couple's seventeen years of cohabitation led her to abandon any interest in the marriage itself and to repel all efforts by the husband to save it. The wife was awarded a payment equal to about one-quarter of the husband's net worth - a sum which could be raised by the sale of a part of the husband's lands, but which would leave him with enough of a farming business to enable him to support himself and make a monthly payment toward the maintenance of the wife and afflicted daughter.

The difficulties of application of paragraph $8(a)$, which directs consideration of the contribution of the spouses to the marriage partnership, are enhanced by the identification of a different species of contribution in paragraphs $(b)$ and $(c)$. These two paragraphs concentrate on the contribution of a spouse to the "acquisition, conservation or improvement" of a given asset or assets. Paragraph $(c)$ excludes any reference to the "operation or management" of property, making it likely that it applies to contributions made to property other than the "business, farm, enterprise or undertaking" contemplated by paragraph (b). The standard of measurement envisaged by paragraphs $(b)$ and $(c)$ is distinctly different from that countenanced by paragraph $(a)$, and it is to be hoped that they will not operate to downgrade the importance of the more general form of contribution recognized by paragraph (a).

As a key to the intended interpretation of paragraphs $(b)$ and $(c)$, it is appropriate to ask: what shortcoming of the existing law do they remedy? In answer, not only do they emphasize that the court is not curtailed by a finding of an interest under existing law principles from going on to redistribute that interest in the exercise of its discretion under this Act, but also they clarify that, in determining the proportions of sharing, account is to be taken of both non-financial and indirect contributions whose operative influence under the existing law is somewhat uncertain. Indeed, the reference to indirect contributions in each of paragraphs $(b)$ and $(c)$ may serve to reintroduce the contribution of the spouse in the home which is provided for in paragraph $(a)$ so as to ward off any temptation to revert to the "asset by asset" approach.

The 1976 New Zealand legislation provides for the division of the residue of matrimonial property equally unless the contribution of one spouse "to the marriage partnership has clearly been greater than that of the other spouse". ${ }^{164}$ Atkin emphasizes:165

... that the equal division rule is departed from not by proof of a greater contribution to a particular asset nor to the remaining matrimonial assets in general but by proof of a greater contribution to the marriage as a whole.

163. [1978] 3 W.W.R. 205 at 208.

164. Matrimonial Property Act 1976 (No. 166 of 1976), s. 15(1).

165. Atkin, supra n. 130 at 84-5. 
He cites the example of a successful businessman whose wife has played no direct part in the running of his business: in order to overcome the presumption of equal sharing, that man:166

... will have to rely upon more than his industry and skill in business and his wife's business inactivity ... He will have to adduce evidence that he played overall a much greater part in all the other aspects of the marriage as well.

In the absence of any express guidance as to the interrelationship of section 8's three "contribution" paragraphs, one may hope, although it can not be said with confidence, that this will be the Alberta result.

The role to be played by economic (as opposed to marital) misconduct in assessing the respective contributions of the spouses may be problematic. Hewitt comments on the difficulty which the Saskatchewan courts have experienced in maintaining a separation between contribution and detriment in the economic sphere of spousal activity .167

In Larson v. Larson, ${ }^{168} \mathrm{Mr}$. Justice MacPherson determined that, but for the husband's laziness and poor business sense, the assets of the family would have been substantially greater. In view of the wife's industriousness, he determined she had contributed substantially more to the marriage than her husband, and made an order very favourable to the wife. In Meston $v$. Meston ${ }^{169}$ the spending habits of the wife were considered to have been somewhat harmful to the economic status of the family. In Ulmer v. Ulmerizo the wife's business acumen, sense of responsibility, maturity and administrative qualities, coupled with a lazy, unemployed husband so impressed the judge that the wife was awarded $70 \%$ of the matrimonial assets. Finally, the husband's miserly attitude was undoubtedly a factor in the order for the wife in Moczyrok v. Mozcyrok.1"1

Decisions have, however, gone the other way: in Bowser v. Bowser, 172 a wife who had contributed little was allowed some benefit in the matrimonial assets by a judge who considered it his overriding obligation to make a fair and equitable order; and, in Galambos.v. Galambos, 173 a wife who "had made a very small contribution and was guilty of serious economic misconduct ... [nevertheless] was awarded one half of the proceeds from the sale of the matrimonial home"..174

Hewitt175 suggests that the problem of divorcing economic misconduct from contribution is further aggravated in Saskatchewan by the use of the phrase 'prudent management' in section 22(4). Although Alberta's paragraph $8(b)$ does not qualify the character of the 'management' referred to, any assessment of the contribution made by a spouse to the management of property subject to distribution may be predicted to admit of its negative, as well as its positive aspects - provided that they surpass the merely trivial.176

166. Id. at 85 .

167. Hewitt, supra n. 96 at 267.

168. Unreported decision, Nov. 28, 1975 (Sask. Q.B.)

169. Unreported decision of MacDonald J., Nov. 19, 1976 (Sask. Q.B.).

170. Unreported decision of Sirois J., Dec. 13, 1976 (Sask. Q.B.).

171. Unreported decision of MacPherson J., March 4, 1977 (Sask.Q.B.).

172. (1975) 24 R.F.L. 394 (Sask. Q.B.).

173. Unreported decision of Sirois J., May 19, 1977 (Sask. Q.B.).

174. Hewitt, supra n. 96 at 266.

175. Id. at 267.

176. Note the correlation between economic misconduct and the dissipation of property discussed under heading X.B (1) below. 


\section{(d) Financial resources and earning capacity}

The reference to "income, earning capacity, liabilities, obligations, property and other financial resources" in paragraph $8(d)$ does not stretch into the future. Probably, the future was excluded by design since the predecessor Bill 102,17n the minority proposals of the Institute of Law Research and Reform, ${ }^{178}$ and section 25 of England's Matrimonial Causes Act 1973179 from which many of these provisions have evolved all refer to "the foreseeable future" rather than "the time of the trial." The English Act, it will be recalled, combines property distribution and support within one statute concerned with overall financial provision, and the cases discussing this factor are of limited usefulness to explain the Alberta wording since they tend to emanate a maintenance flavour. The Alberta paragraph, in contrast, appears to contemplate emphasis on the changes in the property positions of each spouse between marriage and breakdown, signified by the time of the trial. The wording of the provision opens the door to a weighing of circumstances such as a pension from a previous marriage lost by reason of the widow or widower's subsequent, unsuccessful remarriage, or the career years passed up by a spouse whose contribution has been made in the home. 180

\section{(e) Duration of marriage}

This factor also is contained in the English legislation, ${ }^{181}$ although there it is combined with the age of the parties and the decisions once again tend to turn on maintenance considerations. The Ontario legislation, ${ }^{182}$ which permits departure from the rule of equal sharing of family assets where a division in equal shares would be inequitable, includes a similar head upon which one writer has commented as follows:183

Presumedly, if the marriage has been unusually short in duration, then the dependent spouse may receive substantially less than half of the "family assets". But the converse may not necessarily follow; that is, if a marriage has lasted for a very long time and where the parties have cohabited for most or all of that interval, there may be no compelling equity to grant the dependent spouse a share greater than half, although on its face the legislation may sug. gest otherwise.

The logic of this remark falls short for assets acquired during the marriage which are subject to equal sharing under section 7(4). Because a large quantity of assets is unlikely to be amassed during a brief marriage, ordinarily one would be hard-pressed to find reason to depart from the equal sharing standard. Assets falling within the unequal sharing category are another matter: the claim of a spouse, arising out of a short-lived marriage, to section $7(3)$ property may be weak indeed; greater duration may give the claim impetus.

177. Third Session 18th Legislature 26 Eliz. 2.

178. Supra n. 24.

179. (U.K.), c. 18.

180. The possible introduction into consideration of the future financial positions of the spouses is discussed under headings X.B. $(m)$ and XI below.

181. Matrimonial Causes Act 1973 (U.K.), c. 18.

182. Family Law Reform Act, 1978, S.0. 1978, c. 2.

183. Holland, supra n. 127 at 23. 


\section{(f) Property acquired after separation}

Paragraph $8(f)$ encompasses property acquired after separation in fact. While its focus is the time of acquisition of property, the paragraph does not foreclose consideration of contributions made by the spouses to that, or any other, property when they were living separate and apart. Contributions made during such a period have been treated as relevant in Saskatchewan (where it is reasonable to infer that section 22(4)184 is restricted to contributions made by the husband and wife during marriage): 185

In Paquin v. Paquin'186 and Sawyshyn v. Sawyshym187 the fact that the husband had lived in the matrimonial home rent free throughout the period of separation was deemed an important factor in the wife's favour. In Keeler v. Keelerise the parties had lived separate and apart for 10 years during which time the wife had raised the children alone, with little assistance, financial or otherwise from her husband, and was granted an order which reflected this. The exception may be found in Schaik v. Schaik's9 where only the contributions while co-habiting were considered. However, this case involved a short-term marriage during which the parties had, by agreement, kept detailed records of their respective contributions.

The fact that an acquisition occured on the eve of separation might also have a bearing on the distribution ordered although, in the interests of parallelism, it should be remembered that property acquired in contemplation of marriage is exempt as to its value at that time for purposes of the initial categorization of property.

\section{(g) Terms of oral or written agreement}

This paragraph anticipates contracts which do not comply with the requirements of sections 37 and 38 so as to remove the property of the spouses from within reach of Part 1 of the Act. It allows the court to consider understandings entered into on a basis more informal than that required for contracting out. It may contemplate more specifically agreements which have been entered into but which are unfulfilled at the time of the trial in that paragraph $8(i)$ seems to embrace a previous distribution which has been completed in consequence of agreement.

The language appears broad enough to embrace any common intentions of the spouses in respect of property, and where such common intentions are found they may be expected, as now, to fill a persuasive role.

\section{(h) Gift or transfer to a third party}

Where a gift to a third party or a transfer to a mala fides purchaser substantially reduces the matrimonial assets to the detriment of the other spouse, the court may take the amount of the reduction into account in allocating the remaining assets, as section $10(1)(g)$ expressly provides. The power of the court to grant either this or the other relief (i.e., an order under subsections $(1)(e)$ or $(f)$ to recoup a sum of money in respect of the property gifted or transferred, or for the

184. Married Women's Property Act, R.S.S. 1965, c. 340, s. 22 as am. S.S. $1974-75$, c. 29 and thereafter.

185. Hewitt, supra n. 96 at 268-9.

186. Unreported decision of MacDonald J., Nov. 10, 1975 (Sask. Q.B.).

187. Unreported decision of Sirois J., Feb. 6, 1976 (Sask. Q.B.).

188. Unreported decision of MacPherson J., March 10, 1977 (Sask. Q.B.).

189. Unreported decision of Sirois J., Aug. 16, 1977 (Sask. Q.B.). 
return of the property itself, from the third party recipient) available under section 10, however, is predicated upon proof of the intention of the donor or transferor spouse to defeat a claim of the other spouse under Part 1 of the Act, coupled with the actual or constructive knowledge of the recipient of this intention.190 Furthermore, the transaction must have occurred within the year preceding application for a matrimonial property order.191

Paragraph $8(h)$ is much less restrictive, leaving adjustment to the court's discretion whether or not the conditions precedent to resort to section 10 have been satisfied. Where relief has been granted under section 10 , modification of the distribution which would otherwise be awarded in the exercise of the broader section 7 discretion, and in respect of which paragraph $8(h)$ becomes a consideration, may be expected by reason of paragraph $8(j)$.

For a flagrant example of facts warranting the exercise of the court's discretion in favour of the thwarted spouse, imagine a gift of real property conferred on a close relative in circumstances permitting its continued enjoyment by the donor spouse.

(i) Previous distributions; and

\section{(j) Prior court order}

The reference in paragraph $8(i)$ to a previous distribution of property between the spouses by gift or agreement is reminiscent both of section $7(3)(d)$ which places a gift from one spouse to the other in the unequal sharing category, and of paragraph $8(g)$ which directs the considerations of the terms of any agreement between the spouses. The reference to a previous matrimonial property order likewise bespeaks duplicity, in that paragraph $8(j)$ names prior court orders.

As to the policy of paying attention to the details of any earlier distribution, and to the contents of any previous judicial pronouncements concerning the ownership or distribution of property, its importance lies beyond dispute (although in the case of a matrimonial property order, perhaps only property acquired after the date of the earlier order should be available for subsequent distribution). Consider the facts elicited in the recently decided English case of Backhouse v. Backhouse.192 After nearly 19 years of marriage Mrs. Backhouse, without any warning, walked out on her husband and went to live with her paramour. Some three or four months later, she executed a transfer of her interest in their jointly owned home into her husband's sole name. The transfer was without consideration. On her subsequent application for an order of family provision, the court considered the circumstances surrounding the transfer, including the fact that through her management of the family finances together with contributions out of her own earnings Mrs. Backhouse, "a methodical person with very much a business turn of mind",193 had built up the savings which enabled the couple to purchase the home in question. The court

190. S. $10(1)(b)$ and $(c)$.

191. S. $10(1)(d)$.

192. [1978] 1 All E.R. 1158 (Balcombe J.).

193. Id. at 1160 . 
was further influenced by the fact that "[w]hen a marriage has broken down, both parties are liable to be in an emotional state". ${ }^{194}$ Having observed that the "party remaining in the matrimonial home ... has an advantage", 195 and having found that Mrs. Backhouse was motivated to sign over the transfer of her house by the sense of guilt she felt at what she had done,196 the court awarded her "a share in the capital asset, the house, which she helped to create". ${ }^{197}$

A similar result is to be expected under the Alberta Act, whether as a consequence of considerations raised by paragraph $8(i)$ or by reason of the imposition of a resulting trust under the principles of the law of separation of property. Should the transfer be held to be either effective pursuant to agreement so as to pass the total property to the husband, or ineffective so as to leave the beneficial ownership of the one-half interest with the wife, the property would fall to be distributed under the presumption of equal sharing. If, on the other hand, in all the circumstances of the transaction the court were to find an intention on the part of the wife to make a gift to her husband, the property would come within the unspecified sharing category, possibly to the disadvantage of the applicant wife..$^{198}$

\section{(k) Tax liability}

If the tax liability incurred by one spouse as a result of a courtordered property distribution had the effect of depleting his share relative to the share allotted to and retained by the other spouse, the distribution would thereby be rendered inequitable. Paragraph $8(k)$ draws this factor to the attention of the spouses and the court.

\section{(l) Dissipation of property}

The English decision of Martin v. Martin ${ }^{199}$ exemplifies the judicial result which may be expected to follow from the dissipation of property by one spouse to the detriment of the other. In that case, during some six years after the break-up of the marriage the husband dissipated more than $£ 33,000$ in unsuccessful business ventures with another woman while the wife "maintained, if not enhanced the value" of the family farm. The Court of Appeal held that "a spouse cannot be allowed to fritter away the assets by extravagant living or reckless speculation and then to claim as great a share of what is left as he would have been entitled to if he had behaved reasonably"200 and awarded the wife the whole of the beneficial interest remaining in the farm - the major matrimonial asset.

Query whether alterations in the distribution of property would be warranted on the strength of more minor infractions such as mere bad judgment compared with reckless speculation, or unwise management

194. Id. at 1166.

195. Id.

196. Id. at 1164 .

197. Id. at 1168 .

198. As to the consideration which ought to be given to a prior support order, see heading XI.

199. [1976] 3 All E.R. 625 (C.A.).

200. Id. at 629 . 
in lieu of blatantly irresponsible handling. That is to say, should account be taken of such lesser degrees of economic mismanagement?201 ( $m$ ) Any relevant fact or circumstance

Paragraph $8(m)$ constitutes the back door through which such noticeably absent matters as future financial expectations and obligations and the conduct of the spouses may gain entrance. In Saskatchewan, judges have gone beyond the respective contributions of the spouses which they are required to take into account in coming to a fair and equitable decision, and have paid attention both to their future earning capacities and to future obligations in the form of debts, as well as to child rearing, ${ }^{202}$ even without the benefit of a catch-all phrase. Moreover, although in Hewitt's view marital misconduct clearly is not be considered in Saskatchewan and "aside from economic misconduct, judges have successfully maintained a distinction between conduct and contribution", he observed of the cases he reviewed that "a certain degree of overlap is inevitable and undoubtedly some decisions would have been more favourable to the delinquent spouse but for [his] misbehaviour". ${ }^{203}$ In like fashion, Atkin suggests that section 14 of the 1976 New Zealand Act,204 which permits exception from the equal division of certain property in "extraordinary circumstances",205

... lays the way open for argument that matrimonial misconduct may be an extraordinary circumstance. Misconduct which has affected the extent or value of the matrimonial assets, exemplified by the Privy Council in Haldane v. Haldane ${ }^{206}$ as "sluttishness or extravagance on the part of a wife or reckless gambling by a husband,"... may surely be taken into account. But by the same token, there is no reason why marital fault of a more general kind cannot also be considered.

The possibility of the introduction of conduct as a relevant consideration merits comment on the experience in England where the courts are directed to have regard to conduct in deciding whether or not, and in what proportions to distribute matrimonial property. ${ }^{207}$ Developments there were reviewed in a recent article by Margaret Spencer, entitled "Effect of Conduct on Matrimonial Relief",208 and the following account is drawn almost exclusively from this source.

The present position in England was established by the Court of Appeal in Wachtel v. Wachtel, 209 the milestone decision referred to on more than one occasion earlier in this paper. Lord Denning, who delivered the judgement, stated that conduct should only affect the

201. See also the comments on the relationship between contribution to property and economic misconduct made in connection with the dicussion of paragraphs $8(b)$ and (c).

202. Child rearing is embraced in Alberta by paragraph $8(a)$ which includes "any contribution made as a homemaker or parent."

203. Hewitt, supra n. 96 at 267.

204. Matrimonial Property 1976 (No. 166 of 1976).

205. Atkin, supra n. 130 at 84.

206. [1976] 2 N.Z.L.R. 715.

207. See section 25 of the Matrimonial Causes Act 1973 (U.K.), c. 18.

208. (1978) 128 New L.J. 348.

209. [1973] 1 All E.R. 829. 
award and amount of an order for financial provision where it is both 'obvious and gross,' so much so that to order one party to support another whose conduct falls into this category is repugnant to anyone's sense of justice".210 The result is that, even though conduct is specified for consideration in the governing legislation, its weight as a factor is to be downplayed. Later decisions of the English Court of Appeal have approved and followed Wachtel: Trippas v. Trippas;211 Harnett v. Harnett.212

The trial judge in Harnett, gave a definition of obvious and gross conduct:213

... to satisfy the test that conduct must be obvious and gross in the sense that the party concerned must be plainly seen to have wilfully persisted in conduct, or a course of conduct, calculated to destroy the marriage in circumstances in which the other party is substantially blameless.

The Court of Appeal has indicated further that it will not regard conduct as a significant factor where the behaviour of both parties weighs equally in the balance such that a brief affair by a wife with a youth half her age did not justify any reduction in the order for financial provision awarded in her favour. ${ }^{214}$

Factors which have been taken into account by the English courts in deciding whether the conduct complained of is obvious and gross include the length of the time during which the onerous conduct took place;215 and whether it contributed to the marriage breakdown or occurred subsequently.216 Once it has been characterized as obvious and gross, the severity of the conduct will go to the measure of reduction of the miscreant's award.

In a number of other cases, the court has either expressly or impliedly taken one party's conduct into account when distributing the assets of the family under the English legislation:

(1) One such case is Cuzner v. Underdown.217 A husband, lacking knowledge of his wife's adulterous affair with the man she left him for six weeks later, purchased a house in their joint names. The Court of Appeal termed the wife's claim "an astonishing one"218 and awarded the husband the whole interest in the house on the basis that the wife's deception had been obvious and gross and that had the husband realized his wife was committing adultery he would have put the house into his own name alone.

210. Id. at 835 .

211. [1973] 2 All E.R. 1 (C.A.).

212. [1974] 2 All E.R. 764 (C.A.).

213. [1973] 2 All E.R. 593 at 601 (Fam. L. Div.).

214. Harnett v. Harnett [1974] 2 All E.R. 764.

215. Griffiths v. Griffiths [1974] 1 All E.R. 932 (C.A.).

216. W. v. $W$. [1975] 3 All E.R. 970.

217. [1974] 2 All E.R. 351 (C.A.).

218. Id. at 354 per Davies L.J. 
True, the wife was entirely to blame for the breakdown of the marriage, but should her twelve-year contribution as a homemaker and parent, including some years as an (albeit modest) income-earner count for naught?219

(2) In Jones v. Jones, 220 two months after a decree absolute of divorce was granted the husband attacked the wife with a knife. Her wounds included the severance of tendons which caused a 75\% disability of her right hand and prevented her from continuing in her occupation as a nurse. The conduct of the husband was found to have been of such a gross kind that it would be offensive to a sense of justice that it should not be taken into account. The result was that the whole of the beneficial interest in the house was transferred to the wife unconditionally. Conduct, then, may be relevant for the purpose of increasing as well as cutting down a spouse's share in matrimonial property. Moreover, in England "conduct" is not confined to matrimonial misconduct.

(3) Another example is provided by the case of West v. West221 in which the conduct of a wife was found by the Court of Appeal to be both obvious and gross where virtually throughout the marriage the wife had refused to live in the matrimonial home with her husband, but had remained living with her parents. The Court of Appeal affirmed the decision of the trial judge that the word "gross" does not mean gross in any moral sense but merely that the misconduct must be of the greatest importance.

Orders of the English Court of Appeal have also been affected by conduct which may fall short of the "obvious and gross" test:

(1) One example is provided by the case of Weisz v. Weisz.222 The husband in that case was recalcitrant about giving details of his property and indicated his unwillingness to pay support. The court regarded him as thoroughly dishonest man following two hearings and ex parte proceedings to find out the true extent of his assets. In this situation the court ordered a large capital sum and no maintenance.

(2) A second illustration is provided by Bryant v. Bryant.223 In that case, the marriage had been a very stormy one and the husband had a history of imprisonment for breach of injunctions by which deliberate means he had avoided meeting his support obligations.

219. The facts of the more recent case of Backhouse v. Backhouse [1978] 1 All E.R. 1158 , discussed above under subheading X.B.(i), are very similar to those in Cuzner v. Underdown [1974] 2 All E.R. 351 (C.A.). However, the result is markedly different. In deciding Backhouse, Balcombe $\mathrm{J}$. was able to distinguish the precedent established by the earlier case on the basis of the Court of Appeal's holding that, unlike Mrs. Backhouse, Mrs. Cuzner had made no financial contribution to the purchase of the house.

220. [1975] 2 All E.R. 12.

221. [1977] 2 W.L.R. 933.

222. The Times, December 16, 1975.

223. (1976) 6 Fam. L. 108. 
The Court of Appeal directed the husband to transfer to his former wife his interest in the matrimonial home.

The latter two examples may relate more to the choice between periodic and lump sum maintenance than to the apportionment of property. The English legislation, it will be recalled, blends the adjustment of property with the claim to ongoing support to the end of a single award of financial provision, and the ability of the court to weigh the behaviour described in these examples highlights an advantage of the English - and Australian - approach.224 The Matrimonial Property Act does not, of course, preclude the consideration of such matters, for paragraph $8(\mathrm{~m})$ permits the introduction of any relevant circumstance. However, obstacles standing in the way of the enforcement of a support order do not rank among the matters listed for consideration in section 8 . Furthermore, it may be difficult to establish the relevance of such a factor to a scheme of distribution which pivots on the notion of entitlement earned by past contribution and which is, at the same time, conspicuously silent as to the role to be played by future circumstances. The apparent legislative intention is to minimize the influence of future conduct irrespective of its economic portent.225

If the Alberta courts allow the introduction of conduct of any kind - sexual of otherwise and whether contributing to marriage breakdown or occurring thereafter - to influence the distribution of matrimonial property, it is to be hoped that, in keeping with English precedent, they will restrict their considerations to conduct which is so "obvious and gross" as to make an equal distribution of property under section 7(4) "repugnant to anyone's sense of justice."

Another "relevant fact or circumstance" which may be introduced through paragraph $8(\mathrm{~m})$ of the Alberta Act is the fact of remarriage. In the English case of $H$. v. $H ., 226$ the fact that a wife left her husband for a well-off man was taken into account by the court to reduce her share in the former matrimonial home from the one-third interest, recognized initially under the guideline operative in England, to onetwelfth - and this notwithstanding fifteen years of marriage. Sir George Baker, who decided the case, went so far as to assert:227

224. Matrimonial Causes Act 1973 (U.K.), c. 18, ss. 24, 25 and Family Law Act 1975 (Aust.), (No. 53 of 1975).

225. Insofar as the enforcement of a matrimonial property order is concerned, the broad range of powers conferred on the court by section 9 of the Alberta Act (see heading VII above) will enable it to circumvent many of the problems which bedevil the enforcement of matrimonial support orders. This will be most true in the predicted usual case where the order will relate to property which is owned by a spouse at the time of the hearing. Problems of enforcement could arise where the order takes into account property which has been squandered by a spouse, or given to, or transferred to a third party at substantially less than market value, and the wrong acting spouse does not possess enough remaining property to satisfy his obligation of distribution. Difficulties may also present themselves where the property upon which the distributable portions have been calculated exists in the form of an unassignable interest, or a business holding whose economic viability would be risked by division, or where the interest of a third party may be affected by interference with the ownership of the property.

226. [1975] 1 All E.R. 367.

227. Id. at 371. 
If the concept of earning is to be applied to a domestic situation, then it should be applied with all its normal consequences. One is that if the job is left unfinished you do not earn as much.

As in the Weisz228 and Bryant ${ }^{229}$ cases, this reduction is difficult to justify on purely proprietary grounds, and may have more to do with maintenance considerations.

One may wonder whether the share would be increased if the new spouse were poor? In $H$. v. $H .230$ the court thought not, suggesting instead that the circumstance of a wife's remarriage to a poor man would function simply to improve her entitlement to receive the full share of what she had earned. Whatever the state of wealth of the new spouse, its pertinence lies with the assessment of the financial positions of the parties "in the foreseeable future" - those by now familiar words whose absence leaves open to question the relevance of any consideration of their substance under the provisions of the Alberta Act.

Other English authority makes it clear that the mere prospect of remarriage or any weighing of it, even where a spouse is cohabiting with a potential marriage partner, constitutes an irrelevant consideration. ${ }^{231}$ As Lord Denning stated in Wachtel:232

So far as the capital assets are concerned, we see no reason for reducing [the wife's] share. After all, she has earned it by her contribution in looking after the home and caring for the family. It should not be taken away from her by the prospect of remarriage.

Although, in $H$. v. $H$., Sir George Baker accepted the sense of this position in relation to "the prospect, chance or hope of remarriage", he nevertheless saw reason to distinguish from it "the fact of remarriage which does not admit of speculation". ${ }^{233}$

While the distinction between the fact, as opposed to the possibility, of remarriage may be defensible under the English legislation which mixes matrimonial support together with property apportionment, consideration even of the fact of remarriage rests imcompatibly with the notions of earned entitlement and past contribution which lie at the heart of Part 1 of Alberta's Matrimonial Property Act.

\section{RAMIFICATIONS FOR SUPPORT}

As was noted in the Introduction, the rationale underlying the entitlement of a spouse to a matrimonial property order is quite distinct from that upon which any claim to ongoing support out of the financial resources of the other spouse is founded: whereas the latter is a consequence primarily of need on the one hand coupled with an ability to pay on the other, the former is more in the nature of an earned right.

228. The Times, December 16, 1975.

229. (1976) 6 Fam. L. 108.

230. [1978] 1 All E.R. 367.

231. Wachtel v. Wachtel [1973] 1 All E.R. 829; Trippas v. Trippas [1973] 2 All E.R. 1.

232. [1973] 1 All E.R. 829 at 841.

233. [1975] 1 All E.R. 367 at 371. 
The obvious interrelationship between the two subjects deserves comment in light of the enactment of the Matrimonial Property Act which deals with property in isolation of support rights. As the Institute of Law Research and Reform commented in its Report on Matrimonial Support:234

In a comparatively small number of cases, division of property may obviate the need for any support. In a greater number it may affect the need of a wife or husband for support, and it may detract from the ability of a husband or wife to provide it. In most cases, however, there will be a continued need for the provision of support.

Often a support order will have been obtained or an agreement entered into before application is brought for a matrimonial property order, perhaps before there is sufficient evidence of marriage breakdown to satisfy one of the jurisdiction-conferring conditions of section 5 of the Matrimonial Property Act. What is more, immediately after the Act takes effect, a surge of applications may be expected from spouses whose decree nisi of divorce was granted within two years prior to the date of proclamation. Many of these persons already will have been awarded support. Moreover, the lump sum calculation may be suspiciously close to one-half the value of the matrimonial home or of some other major asset owned by the wealthier spouse, the ownership of which the court does not have the power to reapportion directly.

The question of the proper juxtaposition of matrimonial- property and matrimonial support is complicated by the duplicity of judicial jurisdiction over support, the more limited jurisdiction of the Family Court overlapping with that of the Supreme Court. It is further vexed by the constitutional division of legislative competency which gives Marriage and Divorce to Parliament, and Property and Civil Rights in the Province to the Legislature. ${ }^{235}$

Nor does the Matrimonial Property Act fully resolve the relationship between these two subjects, although it does ameliorate the potential for difficulty to an extent in section $17(2)$ by giving the court power to postpone a property decision so that other matters may be determined first or at the same time, as it appears to the court that it is necessary or desirable.

The question of policy remains: in granting an application for a matrimonial property order, ought the court to adjust the proportions of earned entitlement - of right based on the determination of past, ascertainable contributions and circumstances - in light of the terms of a pre-existing support order or agreement based on the needs and financial resources of the spouses which are susceptible of future unpredictable fluctuations and which may lead to variation of the order or agreement relied upon? The Act does not provide for readjustment of a matrimonial property order which becomes inequitable by reason of faulty speculation as to future occurrences. Indeed, as was observed in the discussion under heading $\mathrm{X} \mathrm{B}(d)$, there is good reason to think that the Legislature wanted to downplay, if not altogether eliminate, any consideration of the future financial positions of the spouses.

234. Report No. 27, Edmonton, March 1978, at 12.

235. The British North America Act, 1867, 30 \& 31 Vict., c. 3, ss. 91 (26), $92(13)$. 
The variable aspect of the support obligation militates against its introduction as a factor affecting the distribution of property, notwithstanding that, if it is not considered, the spouses may be put to the inconvenience and expense of launching a separate application for variation of a pre-existing matrimonial support order or for setting aside a prior agreement. Although a single disposition would be more expeditious in the short run, the countervailing risk of injustice in the long run is of far greater moment. Utilization of the provisions of section $17(2)$ will remove some of the awkwardness, for the court may insist that the matter of support, including the variation of an existing order, be addressed in conjunction with the application for a property order. And it may be posited with a measure of confidence that the law of variation of support awarded on divorce, including lump sum amounts, is flexible enough to allow for variation at the time of, or after, a division of property under provincial legislation, at least where that distribution has a substantial effect on the resources of the spouses.

Notwithstanding this proposition, in the interests of fairness, adjustments will be called for during the period of transition following proclamation of the Act and until the modifications of distinction in principle between support and property created by it become firmly bedded in law. In an appropriate case, the court will have to take into account a lump sum amount paid pursuant to court order made under the transparent guise of its jurisdiction governing support, or pursuant to agreement entered into between the spouses, where it constitutes the functional equivalent of a previous distribution of property. ${ }^{236}$

\section{CONCLUSION}

The Bar and the Bench of Alberta carry the tremendous responsibility of ensuring that the Matrimonial Property Act is interpreted in the spirit intended by its enactors. The burden will fall with particular weight on those counsel and judges who initiate the legislation into practice. The specifics of interpretation remain, at this stage, matters ripe for educated speculation. But one point is clear. The legislation is remedial. And the impetus for it came from the failure of the existing judge-made law to accord such recognition to the role undertaken by the homemaker spouse during marriage as would entitle that spouse to a share in the property accumulated by the other spouse when the marriage breaks down. At a minimum, a proper application of the Act should rectify this deficiency. 


\section{APPENDIX I}

Distribution of property

7 (1) The Court may, in accordance with this section, make a distribution between the spouses of all the property owned by both spouses and by each of them.

(2) If the property is

(a) property acquired by a spouse by gift from a third party,

(b) property acquired by a spouse by inheritance,

(c) property acquired by a spouse before the marriage,

(d) an award or settlement for damages in tort in favour of a spouse, unless the award or settlement is compensation for a loss to both spouses, or

(e) the proceeds of an insurance policy that is not insurance in respect of property, unless the proceeds are compensation for a loss to both spouses,

the market value of that property

(f) at the time of marriage, or

$(g)$ on the date on which the property was acquired by the spouse,

whichever is later, is exempted from a distribution under this section.

(3) The Court shall, after taking the matters in section 8 into consideration, distribute the following in such manner as it considers just and equitable:

(a) the difference between the exempted value of property described in subsection (2) (in this subsection referred to as the "original property") and the market value at the time of the trial of the original property or property acquired

(i) as a result of an exchange for the original property, or

(ii) from the proceeds, whether direct or indirect, of a disposition of the original property;

(b) property acquired by a spouse with income received during the marriage from the original property or property acquired in a manner described in clause $(a)$ (i) or (ii);

(c) property acquired by a spouse after a decree nisi of divorce, a declaration of nullity of marriage or a judgment of judicial separation is made in respect of the spouses;

(d) property acquired by a spouse by gift from the other spouse. 
Matters to be considered
(4) If the property being distributed is property acquired by a spouse during the marriage and is not property referred to in subsections (2) and (3), the Court shall distribute that property equally between the spouses unless it appears to the Court that it would not be just and equitable to do so, taking into consideration the matters in section 8 .

8 The matters to be taken into consideration in making a distribution under section 7 are the following:

(a) the contribution made by each spouse to the marriage and to the welfare of the family, including any contribution made as a homemaker or parent;

(b) the contribution, whether financial or in some other form, made by a spouse directly or indirectly to the acquisition, conservation, improvement, operation or management of a business, farm, enterprise or undertaking owned or operated by one or both spouses or by one or both spouses and any other person;

(c) the contribution, whether financial or in some other form, made directly or indirectly by or on behalf of a spouse to the acquisition, conservation or improvement of the property;

(d) the income, earning capacity, liabilities, obligations, property and other financial resources

(i) that each spouse had at the time of marriage, and

(ii) that each spouse has at the time of the trial;

(e) the duration of the marriage;

(f) whether the property was acquired when the spouses were living separate and apart;

$(g)$ the terms of an oral or written agreement between the spouses;

(h) that a spouse has made

(i) a substantial gift of property to a third party, or

(ii) a transfer of property to a third party other than a bona fide purchaser for value;

(i) a previous distribution of property between the spouses by gift, agreement or matrimonial property order;

(j) a prior order made by a court;

(k) a tax liability that may be incurred by a spouse as a result of the transfer or sale of property;

(l) that a spouse has dissipated property to the detriment of the other spouse;

$(m)$ any fact or circumstances that is relevant. 